\title{
Terrestrially derived sediment: response of marine macrobenthic communities to thin terrigenous deposits
}

\author{
Andrew M. Lohrer ${ }^{1, *}$, Simon F. Thrush ${ }^{1}$, Judi E. Hewitt ${ }^{1}$, Katrin Berkenbusch ${ }^{1,2}$, \\ Michael Ahrens ${ }^{1}$, Vonda J. Cummings ${ }^{1}$ \\ ${ }^{1}$ National Institute of Water \& Atmospheric Research, PO Box 11-115, Hillcrest, Hamilton, New Zealand \\ ${ }^{2}$ Present address: US Environmental Protection Agency, 2111 SE Marine Science Drive, Newport, Oregon 97365, USA
}

\begin{abstract}
Coastal marine habitats adjacent to catchments with encroaching human development are likely to experience increased sediment loadings in ensuing decades. Thus, sedimentary disturbance regimes in which coastal marine benthic communities have evolved may be shifting as depositional events exceeding critical thresholds become more frequent. To understand the threat posed by terrigenous sedimentation in an embayment with increasing urban development, we determined the thickness and frequency at which terrigenous sediment deposits begin to affect the benthos. We performed manipulative experiments involving layers of terrigenous sediment $<1 \mathrm{~cm}$ thick in a variety of intertidal habitats in the Whitford embayment, North Island, New Zealand. Results of 3 separate experiments performed at 5 sites were largely consistent. While experimental plots were never completely defaunated, as little as $3 \mathrm{~mm}$ of the terrigenous material was sufficient to significantly alter macrobenthic community structure (measured after $10 \mathrm{~d}$, relative to $0 \mathrm{~mm}$ controls). The direction of change was predominantly negative; the number of individuals and taxa declined as a result of sediment application, as did the densities of nearly every common species. Large bivalves were less affected than smaller ones, and deeper-dwelling species were less affected than ones at the sediment surface. With repeated applications of thin terrigenous layers $(3 \mathrm{~mm}$ thickness, monthly over a 6 mo period), the sandflat sediments gradually became finer (clay volume \% increased), and macrofaunal community composition progressively diverged from controls. To summarise, macrofauna were negatively affected by extremely small amounts of terrigenous sediment, and repeated depositional events did more damage than single ones. With increasing defoliation and excavation of catchment hillsides, the frequency of depositional events of a given intensity is likely to quicken, indicating an enhanced likelihood of macrofaunal disturbance and degradation in estuarine tidal flats. Management decisions that protect coastal catchments may partially ameliorate the threat to the benthos in coastal receiving waters.
\end{abstract}

KEY WORDS: Land-use - Sediment impacts - Terrigenous sediment deposition - Marine benthos · Sandflat · Low intensity $\cdot$ High-frequency disturbance $\cdot$ Self-organized criticality

\section{INTRODUCTION}

Disturbance is a profoundly important element affecting the structure and function of ecological communities (e.g. Dayton 1971, Woodin 1981, Sousa 1984, Pickett \& White 1985, Menge \& Sutherland 1987, Moreno \& Oechel 1991). Although new colonists will eventually replace organisms that die or exit a patch as a result of habitat disturbance, the path to recovery is influenced by myriad factors, many of which vary substantially in space and time (e.g. Sutherland 1974, Denslow 1980, Hobbs \& Mooney 1991, Zajac et al. 1998). At the broad scale, communities can be thought of as mosaics of biotic recovery: the component species 
are reacting to and recovering from variously sized disturbances, perhaps of several types and intensities, dating back to various points in time (Connell 1978, Huston 1979, Yodzis 1986, Tokeshi 1999).

With so many factors potentially influencing disturbance-recovery dynamics, ecologists have been forced to simplify their models and experimental investigations by focusing on specific circumstances. For example, studies of disturbance-recovery dynamics often begin with the complete defaunation of disturbed patches (i.e. simulating catastrophic, lethal effects) (e.g. Rhoads et al. 1978, Mook 1981, Wilson \& Tilman 1993, Dudgeon \& Petraitis 2001, Lohrer \& Whitlatch 2002, Thrush et al. in press). However, species differ in their susceptibilities to disturbance, and sub-lethal forms of disturbance may be widespread and frequent. With species interactions generally considered important in determining the trajectory of succession (Connell \& Slatyer 1977), it is somewhat surprising that recovery from partially defaunated communities has not been emphasized to a greater degree. Another common simplification is to measure or model the response of a community to a single disturbance, as opposed to a regime of repeated disturbances (e.g. Dudgeon \& Petraitis 2001, Lohrer \& Whitlatch 2002, Norkko et al. 2002). Responses to the first, fifth, and $n$th disturbance may differ if the effects of repeated disturbances accumulate and cause a gradual reduction in tolerance to the disturbance agent over time. Alternatively, the experience of repeated exposures may induce physiological or behavioral modifications that gradually increase the level of tolerance over time.

Although the focus on single catastrophic disturbance events has been greatly instructive, it may be more important to study minor disturbance events because of their much greater frequency of occurrence. An inverse relationship between event magnitude and event frequency persists in a variety of natural systems, and Bak (1997) and Sornette (2000) have formalized the concept of 'self-organized criticality' to explain this fundamental relationship. Once the potential energy in a system reaches a critical state, additional inputs can result in disproportionately large release events (which temporarily reduce the potential energy again). Landslides, for example, are thought to be manifestations of 'critical' systems where periods of stasis are interrupted by intermittent events. The same dynamical processes drive both minor and catastrophic events, but the minor events occur with exponentially greater frequency (i.e. conforming to power laws). Most likely, species evolve to cope with minor disturbances that occur relatively often, particularly when those disturbances occur at frequencies greater than the generation time of the species, as this would be adaptive. However, with increasing disturbance inten- sity, the response of the community may shift from negligible to catastrophic, with an intermediate domain consisting of sub-lethal effects and/or mortalities of selected individuals and taxa. Understanding the point at which a minor environmental perturbation becomes a disturbance is important (Tokeshi 1999), especially as human activities are now substantially changing environmental regimes.

Marine sediments are complex mixtures of inorganic and organic materials derived from marine and terrestrial sources (Lopez et al. 1989). Although the presence of terrestrially derived sediment is natural in coastal marine habitats, terrigenous sediment deposition is now considered a broad-scale environmental problem affecting estuaries and coastal habitats around the world (McKnight 1969, Peterson 1985, Lunden \& Linden 1993, GESAMP 1994, Gray 1997, Ellis et al. 2000). Deposits $>30 \mathrm{~cm}$ thick have been documented at the mouth of the Po River in Italy (Hunt 2002) and near the Eel River mouth in California (Wheatcroft 2000). Deposits $>10 \mathrm{~cm}$ thick have been observed atop New Zealand sand flats (Ellis et al. 2000), and large-scale field experiments were performed in New Zealand to mimic this type of disturbance (Norkko et al. 2002, Cummings et al. 2003, Hewitt et al. 2003, Thrush et al. 2003). However, manipulative experiments with terrigenous sediment are rare in general, and faunal responses to thin $(<1 \mathrm{~cm})$ terrigenous deposits have received little attention, despite evidence that they occur with greater frequency and over greater spatial scales (Rothman et al. 1994, Somfai et al. 1994, Bak 1997, Foster \& Carter 1997, Wheatcroft 2000).

Layers of terrigenous material $<1 \mathrm{~cm}$ thick may not defaunate sediments completely (as often happens with thicker deposits; Thrush et al. 2003), but changes to macrobenthic community structure are certainly conceivable. For example, deposit feeders may respond to changes in food quality, as the nutritional characteristics of terrigenous sediments (e.g. levels of carbon, protein, carbohydrate, microbial biomass, chl a) can differ substantially from those of marine sediments (Cummings et al. 2003). Changes to the cohesiveness of surface sediments, likely to occur when fine terrigenous material is deposited atop coarser marine sands, may affect the infauna's ability to maintain contact with the sediment-water interface; this is an important requirement for many benthic species, particularly for newly settled larvae and small surface-feeding organisms (e.g. Rhoads \& Young 1970, Levinton 1972, Thrush et al. 1996). Overexposure to fine particles may lead to clogging of filter-feeding appendages of many benthic species, thus affecting scope for growth and reproduction (e.g. Peddicord 1976, Grant \& Bacher 1998, Ellis et al. 2002). Terrigenous sediment deposits may also inhibit diffusive and advective transport of materials across the 
sediment-water interface, acting as a cap that alters pore-water geochemistry in the underlying marine sediment column. Finally, sediment characteristics are known to affect larval recruitment, and thin layers of terrigenous material could deter larval colonists (Woodin et al. 1998, Marinelli \& Woodin 2002).

In the Auckland region, human population size is projected to reach 2 million by 2050 and the rates of urban and semi-rural development are among the highest in New Zealand. This phenomenon is evident in an area surrounding the Whitford embayment, $17 \mathrm{~km}$ east of central Auckland, an area of recent development and high growth potential (Fig. 1). Because human alteration of the 3 main catchments surrounding the estuary will likely increase the loadings of terrigenous sediment, information regarding the ecological impacts of such loadings is critical to effective coastal management. Although the information gained by studying the Whitford system will be most applicable to coastal managers in northern New Zealand, the study has broad relevance in any location where steep catchments, heavy rains, and human activities are associated with problems of terrigenous sediment run-off. In this regard, New Zealand is considered to be well representative of many places throughout the Pacific Rim (Milliman 1991).

To test our central hypothesis, that deposits of terrigenous sediment $<1 \mathrm{~cm}$ thick negatively affect macrobenthic communities, we performed 3 field experi-

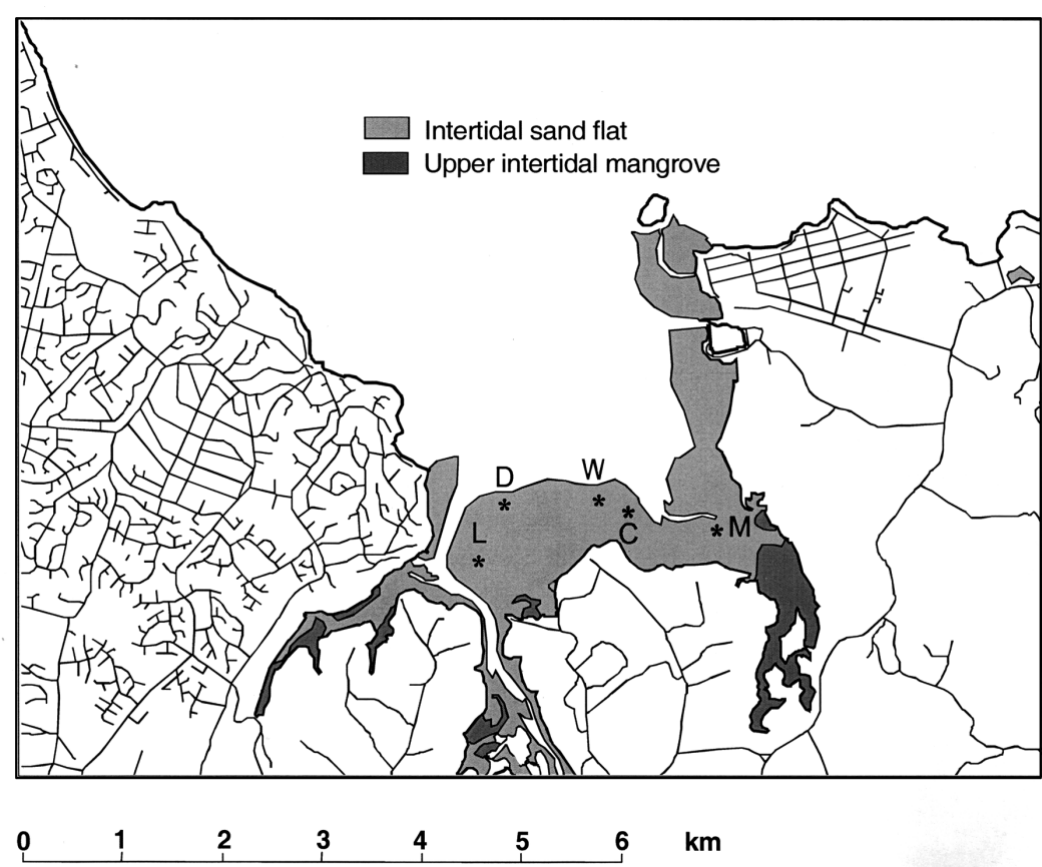

Fig. 1. Whitford embayment $\left(36^{\circ} 54^{\prime} \mathrm{S}, 174^{\circ} 57^{\prime} \mathrm{E}\right)$, on the east coast of the North Island, New Zealand. Note the encroaching development on the western flank of the embayment as a result of suburban sprawl from Auckland, New Zealand's largest city. The 5 experimental sites are indicated with asterisks (*) ments on intertidal sandflats in the Whitford embayment. Specific aims of the research were (1) to identify the thickness of terrigenous sediment that produced measurable changes in macrobenthic community structure, (2) to determine the response of macrofauna to single versus repeated applications of sediment, and (3) to understand the generality of response in a variety of intertidal soft-sediment habitats.

\section{MATERIALS AND METHODS}

Study sites. Five sites were selected within the Whitford embayment, North Island, New Zealand (Fig. 1). The sites were chosen to represent a variety of intertidal sandflat habitats that encompassed a range of hydrodynamic conditions, sediment properties, and benthic community types. Sites C and W were approximately $200 \mathrm{~m}$ apart, located at mid-tide level, and exposed to similar hydrodynamic conditions; live cockles, empty shells, and shell fragments were conspicuous at Site C, but not at Site W. Site L was positioned at a lower intertidal elevation and was influenced by strong tidal currents. Site M was muddier, positioned near the edge of mangrove habitat. Site D was in a location more exposed to wind-waves. The maximum distance between sites was nearly $2 \mathrm{~km}$.

Application of terrigenous sediment. Terrigenous material was obtained from a hillside excavation in the Whitford catchment. The dry soil was broken apart and then mixed with seawater (ratio 1:2) to produce a sedimentseawater slurry. The slurry was passed through a 1 to $2 \mathrm{~cm}$ mesh sieve and the filtrate stored overnight in a large vat. Additional mixing was done after transport to the experimental sites, just prior to sediment application. Thus, we were able to apply terrigenous sediment of similar natural composition to every experimental plot. The sediment in this slurry was dominated by fine particles, with $78 \%$ $<63 \mu \mathrm{m}$ (see 'Results', Table 1).

In the field, a boundary for each experimental plot was first defined using thin strips of metal $(10 \mathrm{~cm}$ wide $\times$ $7.5 \mathrm{~m}$ long). The strips of metal were formed into rings and inserted into the sediment to enclose circular areas of $4.5 \mathrm{~m}^{2}$. Depending on treatment type (i.e. thickness of terrigenous deposit), a measured quantity of slurry was carefully sprinkled onto the surface of the sediment inside each metal ring. Applied at low tide, the terrigenous 
Table 1. Sediment particle size in plots at Sites C and W at the beginning and end of Expt 1 (Days 1 and 10, respectively). Data are given as volumetric composition ( $\%$; mean $\pm 1 \mathrm{SE})$. Column headings indicate treatments. Composition of the experimental terrigenous sediment is also given

\begin{tabular}{|c|c|c|c|c|c|c|c|}
\hline \multicolumn{2}{|c|}{ Wentworth sediment grain size class } & \multirow[t]{2}{*}{ Control } & \multirow[t]{2}{*}{$1 \mathrm{~mm}$} & \multirow[t]{2}{*}{$3 \mathrm{~mm}$} & \multirow[t]{2}{*}{$5 \mathrm{~mm}$} & \multirow[t]{2}{*}{$7 \mathrm{~mm}$} & \multirow{2}{*}{$\begin{array}{c}\text { Terrigenous } \\
\text { sediment }\end{array}$} \\
\hline \multicolumn{2}{|l|}{ Site C } & & & & & & \\
\hline \multirow[t]{6}{*}{ Day 1} & Clay $(0-3.9 \mu \mathrm{m})$ & $2.8 \pm 1.0$ & $4.6 \pm 0.2$ & $7.4 \pm 0.6$ & $10.5 \pm 2.5$ & $9.0 \pm 0.1$ & 12.1 \\
\hline & Silt $(3.9-63 \mu \mathrm{m})$ & $0.1 \pm 0.0$ & $0.3 \pm 0.1$ & $0.6 \pm 0.1$ & $0.5 \pm 0.2$ & $0.9 \pm 0.5$ & 66.0 \\
\hline & $\begin{array}{l}\text { Very fine and fine sand } \\
(63-250 \mu \mathrm{m})\end{array}$ & $95.6 \pm 1.2$ & $93.5 \pm 0.6$ & $90.3 \pm 0.8$ & $88.0 \pm 2.8$ & $89.5 \pm 0.7$ & 19.9 \\
\hline & Medium sand $(250-500 \mu \mathrm{m})$ & $0.3 \pm 0.1$ & $0.4 \pm 0.2$ & $0.3 \pm 0.1$ & $0.4 \pm 0.1$ & $0.2 \pm 0.0$ & 2.0 \\
\hline & $\begin{array}{l}\text { Coarse and very coarse sand } \\
(500-2000 \mu \mathrm{m})\end{array}$ & $0.4 \pm 0.1$ & $0.2 \pm 0.1$ & $0.2 \pm 0.0$ & $0.1 \pm 0.0$ & $0.1 \pm 0.0$ & 0 \\
\hline & Gravel $(>2000 \mu \mathrm{m})$ & $0.8 \pm 0.1$ & $0.9 \pm 0.3$ & $1.2 \pm 0.6$ & $0.3 \pm 0.2$ & $0.2 \pm 0.1$ & 0 \\
\hline \multirow[t]{6}{*}{ Day 10} & Clay $(0-3.9 \mu \mathrm{m})$ & $4.4 \pm 1.2$ & $4.3 \pm 0.9$ & $6.0 \pm 1.3$ & $7.0 \pm 1.1$ & $13.5 \pm 4.0$ & \\
\hline & Silt $(3.9-63 \mu \mathrm{m})$ & $0.3 \pm 0.0$ & $0.4 \pm 0.1$ & $0.4 \pm 0.1$ & $2.3 \pm 1.3$ & $0.8 \pm 0.2$ & \\
\hline & $\begin{array}{l}\text { Very fine and fine sand } \\
(63-250 \mu \mathrm{m})\end{array}$ & $91.2 \pm 2.0$ & $89.6 \pm 4.6$ & $87.5 \pm 3.6$ & $88.5 \pm 1.4$ & $84.4 \pm 4.8$ & \\
\hline & Medium sand $(250-500 \mu \mathrm{m})$ & $0.1 \pm 0.1$ & $0.3 \pm 0.1$ & $0.3 \pm 0.1$ & $0.4 \pm 0.0$ & $0.6 \pm 0.2$ & \\
\hline & $\begin{array}{l}\text { Coarse and very coarse sand } \\
(500-2000 \mu \mathrm{m})\end{array}$ & $0.2 \pm 0.1$ & $0.1 \pm 0.0$ & $0.2 \pm 0.0$ & $0.2 \pm 0.1$ & $0.3 \pm 0.1$ & \\
\hline & Gravel $(>2000 \mu \mathrm{m})$ & $3.8 \pm 2.5$ & $5.3 \pm 3.8$ & $5.7 \pm 4.3$ & $1.6 \pm 1.4$ & $0.4 \pm 0.3$ & \\
\hline \multicolumn{8}{|l|}{ Site W } \\
\hline \multirow[t]{6}{*}{ Day 1} & Clay (0-3.9 um) & $1.5 \pm 0.7$ & $1.4 \pm 0.4$ & $4.1 \pm 0.5$ & $5.3 \pm 1.0$ & $6.0 \pm 0.7$ & \\
\hline & Silt $(3.9-63 \mu \mathrm{m})$ & $0.1 \pm 0.1$ & $0.1 \pm 0.0$ & $0.4 \pm 0.1$ & $1.5 \pm 1.0$ & $0.4 \pm 0.1$ & \\
\hline & $\begin{array}{l}\text { Very fine and fine sand } \\
(63-250 \mu \mathrm{m})\end{array}$ & $98.2 \pm 0.8$ & $97.4 \pm 0.4$ & $94.8 \pm 0.8$ & $92.4 \pm 1.1$ & $93.1 \pm 0.8$ & \\
\hline & Medium sand $(250-500 \mu \mathrm{m})$ & $0.0 \pm 0.0$ & $0.3 \pm 0.1$ & $0.2 \pm 0.1$ & $0.1 \pm 0.0$ & $0.1 \pm 0.0$ & \\
\hline & $\begin{array}{l}\text { Coarse and very coarse sand } \\
(500-2000 \mu \mathrm{m})\end{array}$ & $0.0 \pm 0.0$ & $0.1 \pm 0.0$ & $0.0 \pm 0.0$ & $0.1 \pm 0.1$ & $0.0 \pm 0.0$ & \\
\hline & Gravel $(>2000 \mu \mathrm{m})$ & $0.2 \pm 0.2$ & $0.6 \pm 0.3$ & $0.3 \pm 0.1$ & $0.6 \pm 0.4$ & $0.4 \pm 0.2$ & \\
\hline \multirow[t]{6}{*}{ Day 10} & Clay $(0-3.9 \mu \mathrm{m})$ & $2.4 \pm 0.5$ & $4.5 \pm 1.9$ & $5.4 \pm 0.7$ & $10.1 \pm 3.0$ & $8.2 \pm 2.4$ & \\
\hline & Silt $(3.9-63 \mu \mathrm{m})$ & $0.4 \pm 0.1$ & $1.0 \pm 0.5$ & $0.9 \pm 0.2$ & $0.9 \pm 0.2$ & $1.0 \pm 0.2$ & \\
\hline & $\begin{array}{l}\text { Very fine and fine sand } \\
(63-250 \mu \mathrm{m})\end{array}$ & $96.9 \pm 0.4$ & $85.2 \pm 8.8$ & $93.6 \pm 0.9$ & $88.2 \pm 3.2$ & $89.6 \pm 2.2$ & \\
\hline & Medium sand $(250-500 \mu \mathrm{m})$ & $0.0 \pm 0.0$ & $8.9 \pm 8.9$ & $0.1 \pm 0.0$ & $0.2 \pm 0.1$ & $0.4 \pm 0.1$ & \\
\hline & $\begin{array}{l}\text { Coarse and very coarse sand } \\
(500-2000 \mu \mathrm{m})\end{array}$ & $0.0 \pm 0.0$ & $0.0 \pm 0.0$ & $0.0 \pm 0.0$ & $0.0 \pm 0.0$ & $0.1 \pm 0.0$ & \\
\hline & Gravel $(>2000 \mu \mathrm{m})$ & $0.3 \pm 0.2$ & $0.4 \pm 0.2$ & $0.0 \pm 0.0$ & $0.4 \pm 0.4$ & $0.6 \pm 0.6$ & \\
\hline
\end{tabular}

material was left to settle over 2 tidal cycles, before the rings were removed and the sampling initiated.

The slurry was slightly acidic $(\mathrm{pH} \approx 4)$ upon application in the first experiment (probably due to the electronegativity of clay particles), but $\mathrm{pH}$ rose to 7 to 8 after 1 to 2 tidal cycles. Nevertheless, pH was neutralized with a base (aqueous sodium hydroxide) prior to application in subsequent experiments (see also Cummings et al. 2003).

Plots were spaced $10 \mathrm{~m}$ apart (from midpoint to midpoint) and were randomly positioned in rows running parallel to the shoreline in order to account for any confounding effects due to slight differences in tidal height and inundation. Three different experiments were performed, 2 of them initiated in spring (7 November 2000) and the third in mid-summer (16 January 2001).

Experimental aims. Expt 1 was designed to ascertain the thickness of terrigenous sediment sufficient to affect macrobenthic community structure. In spring 2000, 5 treatments were established at Sites C and W (Fig. 1) to create gradients of terrigenous sediment thickness: $7,5,3$, and $1 \mathrm{~mm}$ treatments, plus $0 \mathrm{~mm}$ controls.

Expt 2 was performed to investigate the response of macrofaunal communities to several successive depositional events. Plots that received $3 \mathrm{~mm}$ of terrigenous sediment in Expt 1 were re-treated with an additional $3 \mathrm{~mm}$ of sediment after $1 \mathrm{mo}$, and then each month for the following 5 mo (a total of 6 applications). Controls (0 mm plots) were maintained over this time period as well.

Expt 3, performed in January 2001, was conducted to assess the response of different macrofaunal communities to terrigenous sediment deposition. Therefore, experimental arrays were established at Sites C, L, D, and $M$ (Fig. 1). Because more sites were sampled during this experiment, the number of treatments per site 
was reduced to 1 and $5 \mathrm{~mm}$ applications along with controls $(0 \mathrm{~mm})$.

Field sampling. Treatments were replicated 4 times per site. The only exceptions were the $7 \mathrm{~mm}$ treatments in Expt 1, which were replicated 2 and 3 times at Sites $\mathrm{C}$ and $\mathrm{W}$, respectively.

To characterize how the sedimentary environment in each plot changed following the application of terrigenous materials, sediment samples were collected on 4 occasions during the experimental period. Cores of sediment ( $2.4 \mathrm{~cm}$ diameter, $2 \mathrm{~cm}$ depth) were taken on Days 1, 3, 7 and 10 to quantify sediment particle-size distribution, organic matter content, and chl a concentration. For each variable, paired core samples were taken and combined prior to analysis. Sediment samples collected for organic matter content and chl a analysis were immediately chilled and stored in the dark.

To quantify the accuracy of our treatment applications and to understand how the terrigenous layers changed over time, deposit thickness was measured from 1 sediment core per plot per date. Sediment shear strength and compaction were determined at 3 haphazard positions within each plot, using a shear vane and a penetrometer, which measured the lateral and vertical forces required to move the top $5 \mathrm{~mm}$ of sediment, respectively.

To quantify the effects of experimental sediment deposition on macrobenthic community structure, 2 larger cores (13 cm diameter, $15 \mathrm{~cm}$ depth) were collected on the final day of each experiment (after 9 to $10 \mathrm{~d}$ ). The thickness of the terrigenous deposit at the top of each core was recorded and then the samples were prepared for transport to the laboratory for analysis.

There were repeated applications of terrigenous sediment during Expt 2. Therefore, to track cumulative effects, repeated measurements were made. Following the first and last applications (November 2000, April 2001), sediments were sampled on Days 1, 3, 7, and 10. Sediment samples (for measurements of particle size distribution, organic matter content, chl a concentration) were also collected each month prior to the reapplication of the terrigenous material. Macrofaunal cores were collected $10 \mathrm{~d}$ following the first and last applications of sediment (November 2000, April 2001), but were not collected in the intervening period in order to minimize effects of sampling disturbance. Sediment sampling locations within each plot were recorded on each occasion to avoid re-sampling of the same area on subsequent visits.

Laboratory analyses. Samples for particle size analysis were pre-treated by digesting sediments in $6 \%$ hydrogen peroxide for $48 \mathrm{~h}$ to remove organic matter, and dispersed using Calgon. Subsequently, the percent volumes for various sediment fractions (gravel, coarse, medium and fine sand, silt and clay) were determined by wet-sieving (for particle sizes $>63 \mu \mathrm{m}$ ) and by using a Galai particle analyzer (for particle sizes $<63 \mu \mathrm{m}$ ) (Galai Cis-100; Galai Productions).

Organic matter content was determined as percent loss on ignition (\% LOI), derived from the reduction in mass when a dried sediment sample $\left(48 \mathrm{~h}\right.$ at $\left.60^{\circ} \mathrm{C}\right)$ is combusted in a muffle furnace $\left(5.5 \mathrm{~h}\right.$ at $\left.400^{\circ} \mathrm{C}\right)$. Chl a was extracted from sediment samples by boiling freeze-dried sediment in $95 \%$ ethanol. The extract was processed using a spectrophotometer, and an acidification step was used to separate degradation products from chl a (Sartory 1982).

Macrofaunal samples were sieved on $0.5 \mathrm{~mm}$ mesh screen, preserved in 70\% isopropyl alcohol, and stained with Rose Bengal. Macrofauna were sorted and identified to the lowest taxonomic level practicable. The common bivalves (Austrovenus stutchburyi and Macomona liliana) were measured and grouped into 3 different size-classes, small $(<5 \mathrm{~mm})$, medium (5 to $15 \mathrm{~mm}$ ) and large (>15 mm).

Statistical analyses. We used a variety of univariate and multivariate statistical procedures (Legendre \& Legendre 1998) to determine patterns in macrobenthic community structure and the significance of variation apparent in each experiment. Data from the duplicate cores collected from each plot were averaged prior to statistical analysis in all cases.

For Expt 1, multivariate analysis concentrated on the gradient of response to terrigenous sediment deposition and was based on the mean data from each treatment. To identify the environmental variables accounting for the variation in macrobenthic community composition, canonical correspondence analysis was conducted using deposit thickness and all sedimentary characteristics as explanatory variables.

For Expt 2, we focused on the variation of response and the divergence of community composition from an initial state. Thus, it was possible to utilize data from each individual plot (rather than treatment means), and ordination diagrams based on the 4 replicates of each treatment (per site per date) were constructed using correspondence analysis. The amount of overlap in community composition was tested for significance using an analysis of similarities procedure (ANOSIM), which is based on a Bray-Curtis similarity matrix created from the original data (Clark \& Gorley 2001).

For Expt 3, site differences dominated the variance among macrofaunal cores, with the effects of terrigenous sediment dependent on the community composition at each site. These interactions were not easily visualized using correspondence analysis (ordination). Thus, we used a classification procedure based on Bray-Curtis similarities calculated from the mean data from each treatment (in raw form, square-root trans- 
formed, and 4th-root transformed). Similarities based on raw data tend to emphasize common taxa, whereas 4th-root transformations better account for rare species. In this case, however, the clustering patterns did not change with transformation type, indicating that the changes in community composition were not confined to a few dominant taxa. The significance of differences was again assessed using ANOSIM.

It was not appropriate to analyze the response of individual species unless they were sufficiently abundant, as conclusions from tests on rare species can be unreliable. However, at least 2 response variables were suitable for univariate analysis in each of the experiments (e.g. number of taxa and number of individuals per core). The most common species (e.g. those averaging $>1$ individual per core across treatments at a site) were analyzed whenever possible as well.

Although the experiments were designed with treatment classes (terrigenous sediment layers of 0,1 , and $3 \mathrm{~mm}$, etc.), deposit thickness varied within treatments at the beginning and end of each experiment (see 'Results'). Since final thickness indicated the dose of terrigenous sediment that persisted throughout the experimental period and until the time of macrofaunal sampling, final thickness was used as an explanatory variable in most of the univariate tests performed. In Expt 1, final thickness was used to develop regression models. Because the experimental array encompassed a relatively large area $\left(2400 \mathrm{~m}^{2}\right)$, spatial gradients in species abundance correlated with physico-chemical and biological factors could have confounded our interpretation of the effects of terrigenous material. However, multiple regression enabled us to assess these effects directly. Specifically, in addition to deposit thickness, the $x$ - and $y$-coordinates of each plot were included in the original regression models, as was the product of the $x$ - and $y$-coordinates (i.e. $x \times y$, a 2D surface variable). Variables were eliminated by backward selection unless significant at $\alpha=0.15$. Variance inflation factors and condition indices were used to rule out problems of collinearity between deposit thickness and the spatial coordinates. Homogeneity of variance was evaluated by plotting residuals vs predicted values, and normality was assessed via normal probability plots and Shapiro-Wilk tests on residuals. In some cases, transformations of the data (e.g. $\log [$ data +1$]$ or square-root[data]) were required to rectify departures from assumptions of the tests. Since we were interested in effects of deposit thickness (and not those of spatial position), partial regression leverage plots were used to present the data in all cases where spatial effects were significant (as in Figs. 3, 5, 8). The partial regression plots were useful, for they demonstrated the response to terrigenous sediment alone (i.e. they removed the influences of other significant con- tributing factors). Partial plot axes do not have any meaningful units, however, so there are difficulties relating deposit thickness level $(\mathrm{mm})$ directly to the variable of interest (e.g. number of Species X).

Results of Expt 2, with just 2 sites and 2 treatments, were analyzed with ANOVA and appropriate post-hoc tests. Again, transformations were used to satisfy assumptions of the test whenever necessary. In Expt 3, analysis of covariance (ANCOVA) models were developed with the site as a class variable and deposit thickness as a continuous one. The significance of the site $x$ deposit thickness interaction term determined whether the response of the macrofauna to terrigenous sediment varied according to site. Due to the smaller area encompassed by each experimental site $\left(1200 \mathrm{~m}^{2}\right.$ at Sites C, D, L, M), we did not account for within-site spatial variation when analyzing these data.

\section{RESULTS}

\section{Expt 1: Five thickness treatments $(0,1,3,5$, and $7 \mathrm{~mm}$ ) at 2 sites}

The terrigenous sediment deposits were clearly visible as light-colored layers at the surface of each treated plot. Laterally shifting sand from the ambient sand-flat habitat accumulated in the experimental plots, with sand ripples partially covering the terrigenous deposits after a single tidal cycle. The terrigenous sediment layers remained visible between the sand ripples as a relatively cohesive layer. After $10 \mathrm{~d}$, the deposits were still evident in most of the experimental plots, with the exception of the thinnest $(1 \mathrm{~mm})$ treatments.

The thickness of the terrigenous deposits decreased over the $10 \mathrm{~d}$ period (Fig. 2), but apart from $1 \mathrm{~mm}$ treatment levels, there was still at least $50 \%$ of the initial thickness present at the end of the experiment. Differences between the target thickness and the actual thickness of terrigenous deposits on Day 1 were due to mm-scale topographic features (depressions, ridges) on the surface of the intertidal sand flat. Statistical analysis confirmed that differences in depositional thickness between treatments were significant at both sites at the beginning and end of the experiment (ANOVAs, $\mathrm{p}<0.0001$ in all cases).

Physical characteristics of the control plots at Sites C and $\mathrm{W}$ changed little over time; sediments were dominated by a high proportion (> $90 \%$ ) of very fine and fine sand, with a small amount $(<5 \%)$ of silt and clay, throughout the experiment (Table 1). In experimental plots at both sites, mud content (silt + clay) increased with increasing deposit thickness. Ten days after the initiation of the experiment, trends of increasing mud content with treatment levels were still apparent (Table 1). 


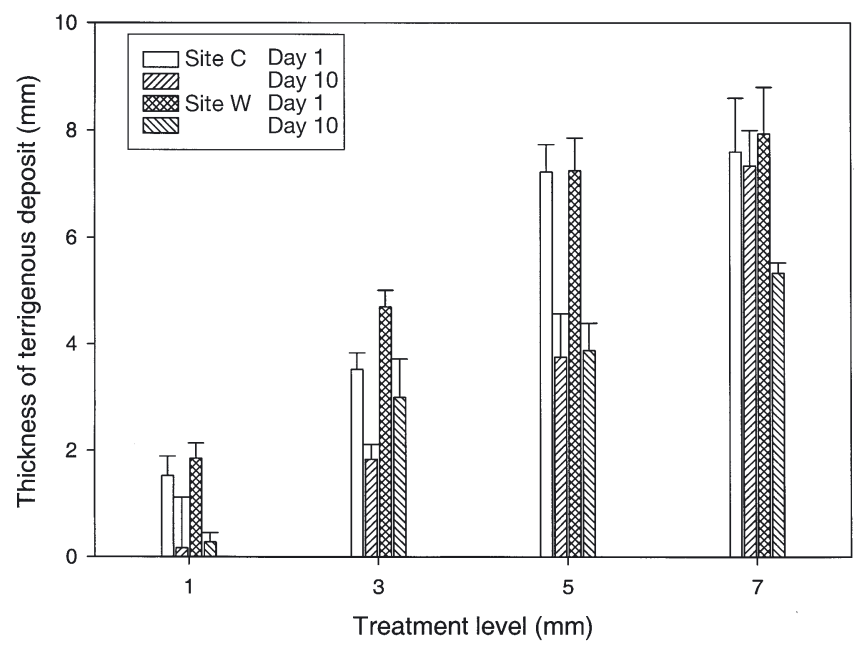

Fig. 2. Thickness of the terrigenous sediment layers in treated plots at the beginning and end of Expt 1. Data are means \pm $1 \mathrm{SE}$. Data from control plots are not included (no terrigenous sediment was added and deposit thickness was $0 \mathrm{~mm}$ in all cases)

Sediment shear strength did not differ greatly between sites (Table 2), but did vary with experimental treatment. Specifically, at the initiation of the experiment, plots with more terrigenous sediment had reduced shear strength. After $10 \mathrm{~d}$, differences between experimental treatments decreased somewhat, although the trends of decreased shear strength with increased deposit thickness were still apparent.

The sediment at Site C contained more organic matter (\% LOI) than sediments at Site W, although the sed- iment organic matter content was low overall. Organic matter content increased slightly according to treatment as deposit thickness was increased from 0 to $7 \mathrm{~mm}$. The relationship between organic matter content and treatment became slightly stronger over the course of the experiment at Site W (i.e. differences between treatments were greater on Day 10 than on Day 1) (Table 2).

Initially, sediment chl a levels at Site $\mathrm{C}$ were double those at Site W. However, at the end of the experiment, chl a content only differed by approximately $25 \%$ between sites. Trends of decreased sediment chl a content with increased terrigenous sediment thickness were not statistically significant at either site (Table 2).

Although sites $\mathrm{C}$ and $\mathrm{W}$ had similar sediment textures (controls, Table 1), the macrobenthic communities were markedly different (Table 3 ). The communities at both sites clearly responded to the deposition of thin layers of terrigenous material over the $10 \mathrm{~d}$ of the experiment. While there was no evidence of mass mortality, the number of taxa and number of individuals declined significantly with increasing terrigenous sediment thickness (Table 4, Fig. 3). In the $7 \mathrm{~mm}$ experimental plots, taxa and individuals decreased by approximately $50 \%$ relative to control plots, and lower treatment levels also had perceptible effects on both community attributes. These patterns were remarkably consistent between the sites despite the greater biological diversity and animal density at Site C.

Correspondence analysis revealed consistent changes in macrofaunal community structure at Sites

Table 2. Physical and biogeochemical characteristics of sediments present in plots at Sites $\mathrm{C}$ and $\mathrm{W}$ at the beginning and end of Expt 1 (Days 1 and 10, respectively). Data are mean values \pm 1 SE. Column headings indicate treatments, which represented a gradient of increasing terrigenous sediment thickness. Results of linear regression analyses are given for each dependent variable on each date (independent variable = deposit thickness; statistically significant results in bold)

\begin{tabular}{|c|c|c|c|c|c|c|c|c|}
\hline Site & Sediment characteristic & Control & $1 \mathrm{~mm}$ & $3 \mathrm{~mm}$ & $5 \mathrm{~mm}$ & $7 \mathrm{~mm}$ & $\mathrm{p}$ & $r^{2}$ \\
\hline \multicolumn{9}{|l|}{ Site C } \\
\hline \multirow[t]{3}{*}{ Day 1} & Shear strength $\left(\mathrm{kg} \mathrm{cm}^{-2}\right)$ & $1.4 \pm 0.2$ & $1.6 \pm 0.2$ & $0.4 \pm 0.2$ & $0.3 \pm 0.3$ & $0.0 \pm 0.0$ & $<0.0001$ & 0.668 \\
\hline & Organic matter content (\%) & $0.8 \pm 0.0$ & $1.0 \pm 0.1$ & $1.0 \pm 0.1$ & $1.2 \pm 0.2$ & $1.0 \pm 0.1$ & 0.0300 & 0.511 \\
\hline & Chl a content ( $\mu \mathrm{g} \mathrm{g}^{-1}$ sediment) & $7.2 \pm 0.7$ & $8.0 \pm 0.9$ & $7.2 \pm 0.3$ & $6.7 \pm 1.0$ & $6.4 \pm 0.7$ & 0.2310 & 0.086 \\
\hline \multirow[t]{3}{*}{ Day 10} & Shear strength $\left(\mathrm{kg} \mathrm{cm}^{-2}\right)$ & $0.5 \pm 0.0$ & $0.5 \pm 0.0$ & $0.4 \pm 0.0$ & $0.4 \pm 0.0$ & $0.3 \pm 0.1$ & $<0.0001$ & 0.623 \\
\hline & Organic matter content (\%) & $1.1 \pm 0.1$ & $1.0 \pm 0.0$ & $1.1 \pm 0.0$ & $1.2 \pm 0.0$ & $1.2 \pm 0.2$ & 0.1410 & 0.148 \\
\hline & Chl a content ( $\mu \mathrm{g} \mathrm{g}^{-1}$ sediment) & $6.6 \pm 0.5$ & $7.0 \pm 0.5$ & $6.8 \pm 0.5$ & $6.8 \pm 0.5$ & $5.8 \pm 0.2$ & 0.5065 & 0.028 \\
\hline \multicolumn{9}{|l|}{ Site W } \\
\hline \multirow[t]{4}{*}{ Day 1} & Shear strength $\left(\mathrm{kg} \mathrm{cm}^{-2}\right)$ & $1.1 \pm 0.1$ & $0.8 \pm 0.1$ & $0.1 \pm 0.0$ & $0.0 \pm 0.0$ & $0.0 \pm 0.0$ & $<0.0001$ & 0.691 \\
\hline & Penetrometer $\left(\mathrm{kg} \mathrm{cm}^{-2}\right)$ & $3.6 \pm 0.2$ & $3.1 \pm 0.2$ & $1.4 \pm 0.3$ & $0.1 \pm 0.1$ & $0.0 \pm 0.0$ & $<0.0001$ & 0.727 \\
\hline & Organic matter content (\%) & $0.6 \pm 0.1$ & $0.6 \pm 0.0$ & $0.7 \pm 0.0$ & $0.8 \pm 0.0$ & $0.8 \pm 0.0$ & 0.7360 & 0.008 \\
\hline & Chl a content ( $\mu \mathrm{g} \mathrm{g}^{-1}$ sediment) & $3.0 \pm 0.2$ & $3.0 \pm 0.1$ & $3.3 \pm 0.2$ & $3.0 \pm 0.2$ & $3.0 \pm 0.4$ & 0.0918 & 0.158 \\
\hline \multirow[t]{4}{*}{ Day 10} & Shear strength $\left(\mathrm{kg} \mathrm{cm}^{-2}\right)$ & $0.5 \pm 0.0$ & $0.6 \pm 0.0$ & $0.5 \pm 0.0$ & $0.4 \pm 0.0$ & $0.3 \pm 0.0$ & $<0.0001$ & 0.845 \\
\hline & Penetrometer $\left(\mathrm{kg} \mathrm{cm}^{-2}\right)$ & $3.0 \pm 0.1$ & $3.0 \pm 0.3$ & $1.9 \pm 0.4$ & $0.6 \pm 0.1$ & $0.5 \pm 0.0$ & $<0.0001$ & 0.866 \\
\hline & Organic matter content (\%) & $0.6 \pm 0.0$ & $0.8 \pm 0.0$ & $0.8 \pm 0.0$ & $0.9 \pm 0.1$ & $0.9 \pm 0.0$ & $<0.0001$ & 0.545 \\
\hline & Chl a content ( $\mu \mathrm{g} \mathrm{g}^{-1}$ sediment) & $4.9 \pm 0.5$ & $5.6 \pm 0.5$ & $5.2 \pm 0.4$ & $4.8 \pm 0.3$ & $4.1 \pm .02$ & 0.1099 & 0.143 \\
\hline
\end{tabular}


Table 3. List of common taxa found in control plots at each site, in order of abundance. Letters next to species name indicate taxonomic class $(\mathrm{P}=$ Polychaeta, $\mathrm{B}=$ Bivalvia, $\mathrm{G}=$ Gastropoda, $\mathrm{A}=$ Amphipoda). Density estimates are given as mean number of individuals per cores $( \pm 1 \mathrm{SE}, \mathrm{n}=4)$

\begin{tabular}{|lrlrr|}
\hline \multicolumn{1}{|c}{ Site C } & \multicolumn{3}{c|}{ Site W } \\
& Density & \multicolumn{2}{c|}{ Species } & Density \\
\hline Aquilaspio aucklandica (P) & $32.5 \pm 6.1$ & Aonides oxycephala (P) & $16.4 \pm 3.1$ \\
Nucula hartvigiana (B) & $20.9 \pm 2.6$ & Orbinia papillosa (P) & $10.4 \pm 2.9$ \\
Austrovenus stutchburyi (B) & $16.4 \pm 4.7$ & Macomona liliana (B) & $6.4 \pm 1.7$ \\
Scoloplos cylindrifer (P) & $13.5 \pm 3.4$ & Aquilaspio aucklandica (P) & $2.9 \pm 0.3$ \\
Heteromastus filiformis (P) & $9.5 \pm 3.9$ & Paracalliopidae (A) & $2.2 \pm 0.9$ \\
Macomona liliana (B) & $6.5 \pm 1.6$ & & \\
Notoacmea helmsi (G) & $4.5 \pm 0.3$ & & \\
Paracalliopidae (A) & $3.1 \pm 1.0$ & & \\
Orbinia papillosa (P) & $1.0 \pm 0.4$ & & \\
& & & \\
\hline
\end{tabular}

$\mathrm{C}$ and $\mathrm{W}$ in relation to deposit thickness (Fig. 3). The first 2 axes of the ordination accounted for 76.9 and $9.1 \%$ of the sample variability respectively. Siterelated differences in benthic community structure were clearly distinguished along the first axis, whereas the second axis indicated effects of experimental sediment applications. Differences in community structure increased with deposit thickness at both sites, and assemblages exposed to the $7 \mathrm{~mm}$ treatment were the most dissimilar to their respective controls.

Canonical correspondence analysis identified 6 environmental variables (of 14 measured) that were related to the ordination of macrobenthic community data $(p=0.0050)$, accounting for $76.7 \%$ of the variability in community composition. Sites $\mathrm{C}$ and $\mathrm{W}$ were discriminated by a combination of factors (levels of $\mathrm{pH}$, chl $a_{\text {, }}$ organic matter; \% coarse + very coarse sand, \% gravel in the sediment) (Fig. 4). However, discrimination of the treatments in ordination space was explained primarily by deposit thickness on Day 10 (i.e. at the same time the macrofaunal cores were collected). Thus, we are confident that the distribution of treatment types in the ordination space resulted from our experimental manipulations, as opposed to unknown spurious factors.

The canonical correspondence analysis also revealed species that changed abundance in relation to the thickness of the terrigenous deposits. Taxa that may have been negatively affected by experimental sediment deposition included polychaetes (Aquilaspio aucklandica, Orbinia papillosa), gastropods (Notoacmea helmsi, Zeacumantus lutulentus, Diloma subrostrata), decapods (Halicarcinus whitei), amphipods (Paracalliopidae, Phoxocephalidae), and bivalves (Nucula hartvigiana, Austrovenus stutchburyi, Macomona liliana). Some of these species were abundant enough for univariate analysis.

None of the common species at either site responded positively to the addition of terrigenous material. While no trend was detected for the polychaete Aonides oxycephala (the most abundant species at Site $\mathrm{W}$ ), the abundance of most other common species declined with increasing deposit thickness (Tables 2 \& 3). In particular, the spionid polychaete Aquilaspio aucklandica declined with increasing deposit thickness at both sites (Fig. 3), as did the orbinid polychaete Orbinia papillosa and a paracalliopid amphipod (Table 4). Another orbinid polychaete, Scoloplos cylindrifer, and a surface grazing limpet, Notoacmea helmsi, both declined at Site C (Table 4). Common bivalves such as Nucula hartvigiana, Austrovenus stutchburyi, and Macomona liliana declined with sediment addition at the sites where they were normally abundant (Table 4 ).

The effects of terrigenous sediment deposition were most pronounced for small bivalves ( $<5 \mathrm{~mm}$ wide), as small individuals of the 3 bivalve species mentioned above all declined with increasing deposit thickness at Site C. Individuals 5 to $15 \mathrm{~mm}$ wide were less affected, as the slope of decline was less severe and/or not significantly different from 0 . Effects on large bivalves (>15 mm) were insignificant in all cases. The tellinid bivalve Macomona liliana was common at both sites, and Fig. 5 illustrates a size-dependent response by this species to the thin layers of terrigenous sediment at both sites.

\section{Expt 2: Repeated applications of 0 and $3 \mathrm{~mm}$ deposits over 6 mo}

When layers of terrigenous sediment $>3 \mathrm{~mm}$ thick were added to the sediment surface, some of the material persisted for at least $10 \mathrm{~d}$. While part of each deposit was probably advected away by physical processes, another portion was likely mixed downward into the sediment column as a result of infaunal bioturbation activities. Thus, the monthly applications of terrigenous sediment during Expt 2 were expected to gradually increase the proportion of fine particles in the sediment over time. Grain size analysis of sediments supported this hypothesis, as the difference in clay content between treatments and controls was greater in April 2001 than it was in November 2000 (i.e. after 6 repeated applications vs a single application).

The response of the macrobenthic community was analyzed in the same manner. We expected greater 
Table 4. Deposit thickness as a predictor of macrobenthic response. Regression models were developed for number of taxa, number of individuals, and abundance of common species present at the 2 experimental sites. Letters next to species name indicate taxonomic class ( $\mathrm{P}=$ Polychaeta, $\mathrm{A}=$ Amphipoda, $\mathrm{B}=$ Bivalvia, $\mathrm{G}=$ Gastropoda). Full regression models included 4 variables ( $x$-position, $y$-position, an $x \times y$ variable, and deposit thickness). Regression statistics (center column) are given for reduced models after variables were eliminated by backward selection (criterion for inclusion was significance at the $\alpha=0.15$ level). The significance of deposit thickness as a predictor of macrofaunal response is indicated at the right of the table. Significant values are indicated with bold type. Note that some of the trends $\left({ }^{\mp}\right)$ are weak and/or marginally significant

\begin{tabular}{|c|c|c|c|c|}
\hline Response variable & Site name & $\begin{array}{l}\text { Significance of } \\
\text { regression model }\end{array}$ & $\begin{array}{l}\text { Significance of deposit thickness } \\
\text { regression model }\end{array}$ & $\begin{array}{l}\text { Negative response to } \\
\text { terrigenous material }\end{array}$ \\
\hline No. of taxa & Site C & $\begin{array}{l}\mathbf{p}<\mathbf{0 . 0 0 0 1} \\
\mathrm{r}^{2}=0.6665\end{array}$ & $\mathrm{p}<0.0001$ & Yes \\
\hline No. of taxa & Site W & $\begin{array}{l}\mathbf{p}<\mathbf{0 . 0 0 0 1} \\
\mathrm{r}^{2}=0.6549\end{array}$ & $\mathrm{p}<0.0001$ & Yes \\
\hline No. of individuals & Site C & $\begin{array}{l}\mathbf{p}<\mathbf{0 . 0 0 0 1} \\
\mathrm{r}^{2}=0.7410\end{array}$ & $\mathrm{p}<0.0001$ & Yes \\
\hline No. of individuals & Site W & $\begin{array}{l}\mathbf{p}=\mathbf{0 . 0 0 0 3} \\
\mathrm{r}^{2}=0.7100\end{array}$ & $\mathrm{p}<0.0001$ & Yes \\
\hline Aquilaspio aucklandica (P) & Site C & $\begin{array}{l}\mathbf{p}<\mathbf{0 . 0 0 0 1} \\
\mathrm{r}^{2}=0.7587\end{array}$ & $\mathrm{p}<0.0001$ & Yes \\
\hline Aquilaspio aucklandica (P) & Site W & $\begin{array}{l}\mathrm{p}<0.0001 \\
\mathrm{r}^{2}=0.7348\end{array}$ & $p=0.0019$ & Yes \\
\hline Orbinia papillosa (P) & Site C & $\begin{array}{l}\mathbf{p}=\mathbf{0 . 0 0 1 9} \\
\mathrm{r}^{2}=0.6436\end{array}$ & $p=0.0260$ & Yes \\
\hline Orbinia papillosa $(\mathrm{P})$ & Site W & $\begin{array}{l}\mathbf{p}<\mathbf{0 . 0 0 0 1} \\
\mathrm{r}^{2}=0.8291\end{array}$ & $p=0.0008$ & Yes \\
\hline Paracalliopidae (A) & Site C & $\begin{array}{l}\mathbf{p}=\mathbf{0 . 0 1 3 7} \\
\mathrm{r}^{2}=0.3237\end{array}$ & $p=0.0137$ & Yes \\
\hline Paracalliopidae (A) & Site W & $\begin{array}{l}\mathbf{p}=\mathbf{0 . 0 0 2 2} \\
\mathrm{r}^{2}=0.5353\end{array}$ & $p=0.0119$ & Yes \\
\hline $\begin{array}{l}\text { Macomona liliana (B) } \\
\quad(<5 \mathrm{~mm})\end{array}$ & Site C & $\begin{array}{l}\mathbf{p}=\mathbf{0 . 0 0 8 6} \\
\mathrm{r}^{2}=0.4696\end{array}$ & $p=0.0041$ & Yes \\
\hline $\begin{array}{l}\text { Macomona liliana (B) } \\
\quad(<5 \mathrm{~mm})\end{array}$ & Site W & $\begin{array}{l}\mathbf{p}=\mathbf{0 . 0 1 6 1} \\
\mathrm{r}^{2}=0.4032\end{array}$ & $p=0.0050$ & Yes \\
\hline $\begin{array}{l}\text { Macomona liliana (B) } \\
\quad(5-15 \mathrm{~mm})\end{array}$ & Site C & $\begin{array}{l}\mathrm{p}=0.5814 \\
\mathrm{r}^{2}=0.1854\end{array}$ & $\mathrm{p}=0.2859$ & No \\
\hline $\begin{array}{l}\text { Macomona liliana (B) } \\
\quad(5-15 \mathrm{~mm})\end{array}$ & Site W & $\begin{array}{l}\mathbf{p}=\mathbf{0 . 0 0 1 7} \\
\mathrm{r}^{2}=0.5501\end{array}$ & $p=0.0322$ & Yes \\
\hline $\begin{array}{l}\text { Macomona liliana (B) } \\
\text { (>15 mm) }\end{array}$ & Site C & $\begin{array}{l}\mathrm{p}=0.2662 \\
\mathrm{r}^{2}=0.1618\end{array}$ & $\mathrm{p}=0.7745$ & No \\
\hline $\begin{array}{l}\text { Macomona liliana (B) } \\
\text { (>15 mm) }\end{array}$ & Site W & $\begin{array}{l}\mathbf{p}=\mathbf{0 . 0 3 3 2} \\
\mathrm{r}^{2}=0.3467\end{array}$ & $\mathrm{p}=0.1795$ & No \\
\hline $\begin{array}{l}\text { Austrovenus stutchburyi (B) } \\
\text { (<5 mm) }\end{array}$ & Site C & $\begin{array}{l}\mathbf{p}<\mathbf{0 . 0 0 0 1} \\
\mathrm{r}^{2}=0.7257\end{array}$ & $p=0.0041$ & Yes \\
\hline $\begin{array}{l}\text { Austrovenus stutchburyi (B) } \\
\quad(5-15 \mathrm{~mm})\end{array}$ & Site C & $\begin{array}{l}\mathbf{p}=\mathbf{0 . 0 4 2 0} \\
\mathrm{r}^{2}=0.3447\end{array}$ & $p=0.1419$ & Yes $^{i}$ \\
\hline $\begin{array}{l}\text { Austrovenus stutchburyi (B) } \\
\text { (>15 mm) }\end{array}$ & Site C & $\begin{array}{l}\mathbf{p}<\mathbf{0 . 0 0 0 1} \\
\mathrm{r}^{2}=0.6226\end{array}$ & $p=0.1510$ & No \\
\hline $\begin{array}{l}\text { Nucula hartvigiana (B) } \\
\quad(<5 \mathrm{~mm})\end{array}$ & Site C & $\begin{array}{l}\mathbf{p}=\mathbf{0 . 0 0 3 4} \\
\mathrm{r}^{2}=0.5321\end{array}$ & $p=0.0568$ & Yes \\
\hline Scoloplos cylindrifer $(\mathrm{P})$ & Site C & $\begin{array}{l}\mathbf{p}=\mathbf{0 . 0 0 9 5} \\
\mathrm{r}^{2}=0.6190\end{array}$ & $p=0.0166$ & Yes \\
\hline Heteromastus filiformis $(\mathrm{P})$ & Site C & $\begin{array}{l}\mathbf{p}=\mathbf{0 . 0 0 2 6} \\
\mathrm{r}^{2}=0.6920\end{array}$ & $p=0.0146$ & Yes \\
\hline Notoacmea helmsi (G) & Site C & $\begin{array}{l}\mathbf{p}=\mathbf{0 . 0 0 0 3} \\
\mathrm{r}^{2}=0.7780\end{array}$ & $p=0.0463$ & Yes \\
\hline $\begin{array}{l}\text { Aonides oxycephala }(\mathrm{P}) \\
\text { (top } 0-2 \mathrm{~cm} \text { of sediment) }\end{array}$ & Site W & $\begin{array}{l}\mathbf{p}=\mathbf{0 . 0 0 1 4} \\
\mathrm{r}^{2}=0.4284\end{array}$ & $p=0.1376$ & Yes $^{\mp}$ \\
\hline $\begin{array}{l}\text { Aonides oxycephala }(\mathrm{P}) \\
\quad \text { (bottom } 2-15 \mathrm{~cm} \text { of sedimer }\end{array}$ & $\begin{array}{l}\text { Site W } \\
\text { nt) }\end{array}$ & $\begin{array}{l}\mathrm{p}=0.5201 \\
\mathrm{r}^{2}=0.0248\end{array}$ & $\mathrm{p}=0.5201$ & No \\
\hline
\end{tabular}



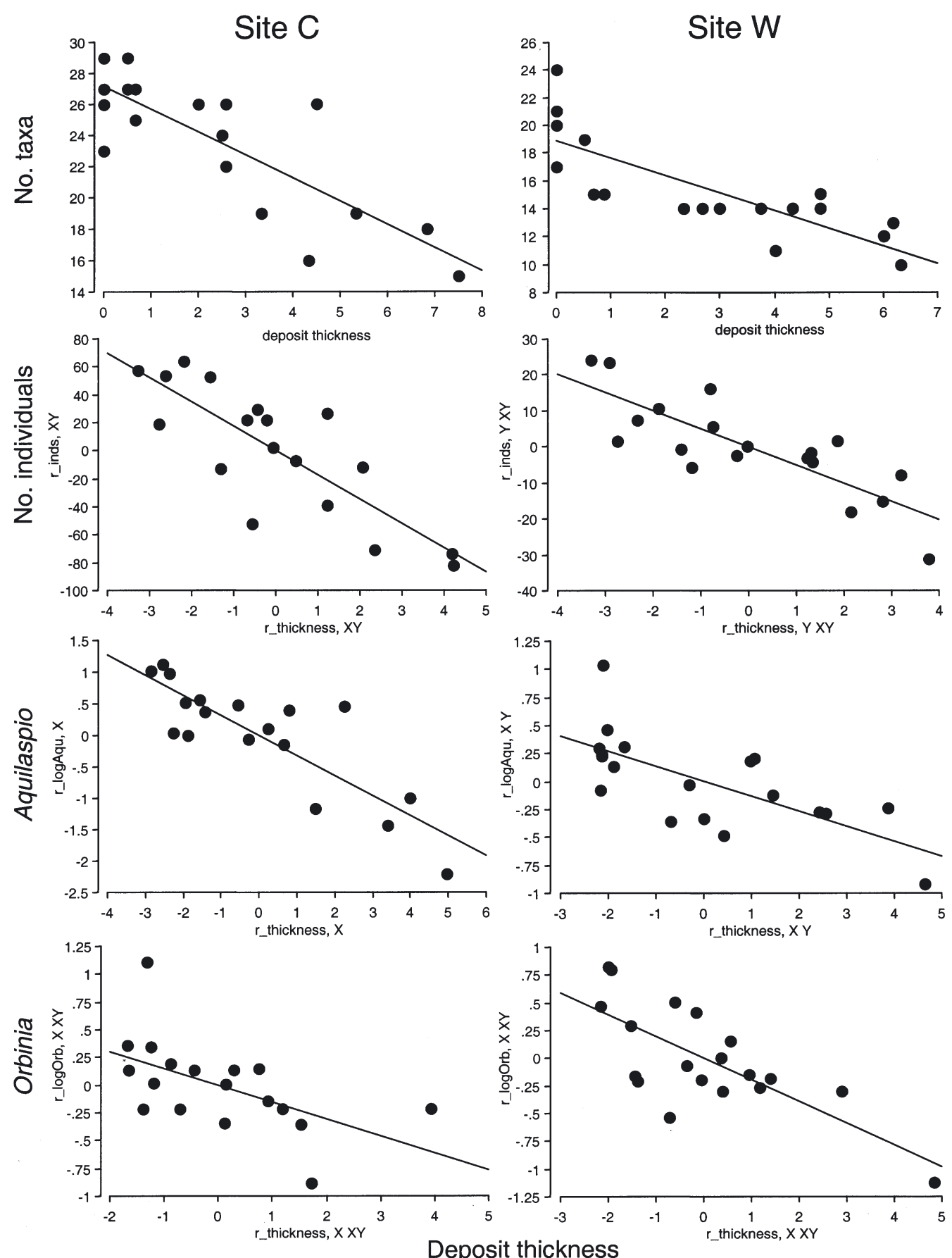

Fig. 3. Response of macrofauna to terrigenous deposits of varying thickness in Expt 1. Deposit thickness (mm) at the end of Expt 1 is plotted versus the number of macrobenthic taxa. Partial regression leverage plots are given for 3 other response variables (number of individuals, Aquilaspio aucklandica, Orbinia papillosa), since positional effects were significant for each. Partial regression leverage plots show the response to deposit thickness alone, after removing the influence of spatial variables that were significant

differences in community composition between treatments and controls in April 2001 than in November 2000. At Site $\mathrm{C}$, the average percent dissimilarity of macrofauna in treatments versus controls increased over time from $38 \%$ in November to $43 \%$ in April.
However, for both dates, the treatment-control differences were not significant (ANOSIM, $p=0.771$ and $p=$ 0.286). At Site $W$, treatment-control dissimilarity rose from 46 to $56 \%$ over the 6 mo period, and differences were significant in April (ANOSIM, $p=0.029$ ). Ordina- 


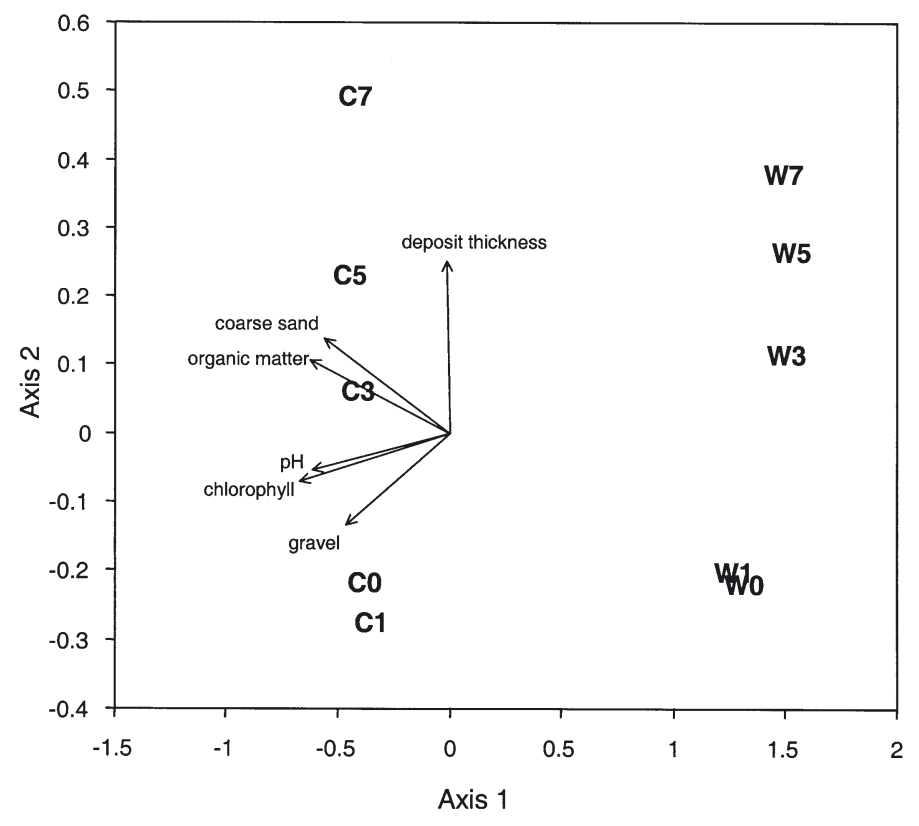

Fig. 4. Ordination of macrobenthic community data at the end of Expt 1. Sites C and W were clearly separated along the horizontal axis (Axis 1, which explained $76.9 \%$ of sample variability). Treatments ( $0=$ control, $1=1 \mathrm{~mm}, 3=3 \mathrm{~mm}$, etc.) were separated along the vertical axis (Axis 2, which explained $9.1 \%$ of sample variability). Axes in ordination plots are dimensionless. Mean data per treatment per site were used in this analysis. Six environmental variables (of 14 measured) were significantly related to the ordination of macrobenthic community data; the arrows indicate the direction and relative magnitude of their influence

tion of the data encapsulated the trends at both sites (Fig. 6), indicating greater differences between treatment and control plots following 6 mo of repeated terrigenous sediment addition.

In general, the macrobenthic communities at Sites C and $\mathrm{W}$ responded negatively to the deposition of terrigenous material (i.e. fewer taxa, fewer individuals) both in November and in April. The negative responses of common species such as Aquilaspio aucklandica and Macomona liliana were generally consistent between dates as well. Trends indicative of cumulative degradation (i.e. larger treatment-control differences following 6 repeated applications of sediment, relative to just 1) were difficult to detect for individual taxa. Since the sediments became only slightly muddier with repeated applications, the concomitant increases in the strengths of treatment effects for macrofaunal species were expected to be subtle. Greater statistical power was likely required to detect such changes (recall, $\mathrm{n}=4$ treatment $^{-1}$ date $^{-1}$ ). Further complicating matters, between November and April species densities and size structures changed as a result of seasonal recruitment, growth, and mortality.

\section{Expt 3: Generality across 4 sites with treatments of 0,1 , and $5 \mathrm{~mm}$}

Visual differences between treatments persisted throughout the third experiment at Sites C, D, L, and M. The $1 \mathrm{~mm}$ deposits changed the most over time due to erosion and reworking. At the end of the experiment, at all 4 sites, deposit thickness was significantly greater in $5 \mathrm{~mm}$ treatments than it was in controls or $1 \mathrm{~mm}$ treatments (Tukey's post hoc test, $\mathrm{p}<0.05$ for all).

The sediments at all 4 intertidal sites were dominated by very fine and fine sands (particle size 63 to $250 \mu \mathrm{m}$; Table 5). Site $\mathrm{M}$ differed slightly from the others in that its sediments contained a greater proportion of clay initially (sediment from control plots was ca. $25 \%$ clay). The amount of clay in the experimental plots increased with treatment type at all sites except Site M. This may be explained by the clay content of the experimental terrigenous sediment; clay content of the Whitford soil was $12 \%$ (Table 1 ), at least 3 times more than was measured in control sediments at Sites C, L, and D. However, it was roughly half the amount at Site M (Table 5).

Sediments from Site M contained 2 to 3 times more organic matter than sediments from the other 3 sites, where values were generally very low (Table 5). Site L had the greatest sediment chl a content. Trends in the amounts of organic matter and chl a were not correlated to treatment type in any consistent manner among sites.

Sediment compaction (measured with a penetrometer) varied between sites and tended to be greater in controls than in $5 \mathrm{~mm}$ clay treatments, although this was a weak trend (Table 5). Sediment shear strength differed little between sites, or among treatments within sites.

Cluster analysis of community data from all 4 intertidal sites revealed the magnitude of change in community composition between the different treatment levels in the different habitats (Fig. 7). Specifically, the community composition in $5 \mathrm{~mm}$ treatments was distinctly different to that in control and $1 \mathrm{~mm}$ experimental plots. This pattern in community structure was consistent across all habitats, but varied in magnitude between sites. While the difference in community composition was small at Sites C and L (i.e. $<5 \%$ ), it was greater at Sites $M$ and D ( 15 and $\sim 25 \%$, respectively). Therefore, even though community structure differed significantly between habitats (ANOSIM, all pair-wise combinations, $\mathrm{p}<0.001$ ), each macrofaunal community responded to the deposition of terrigenous sediment.

Although the clustering pattern in Fig. 8 revealed a shift in community composition as a result of treatment, information regarding the type of shift (i.e. a 


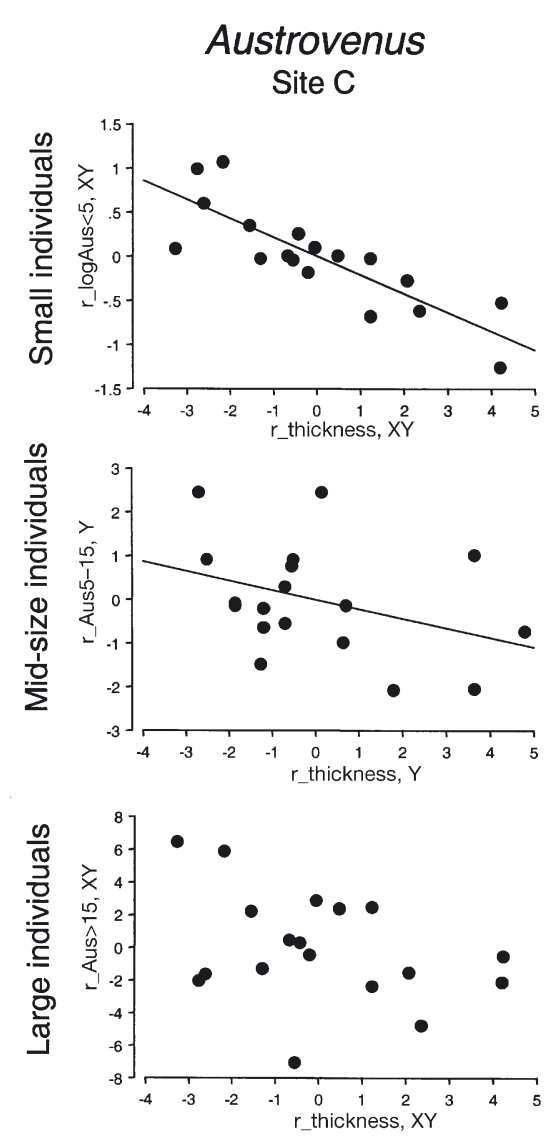

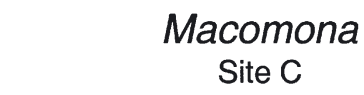
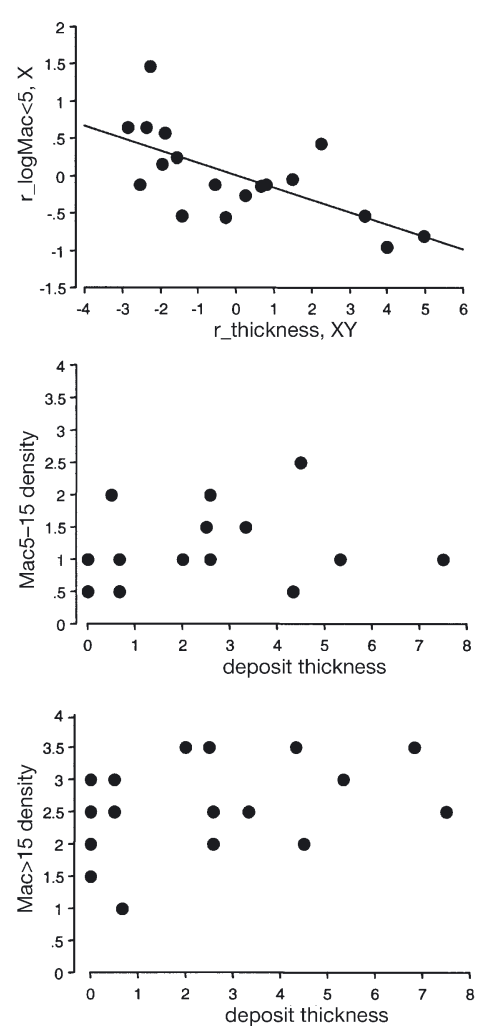

Macomona

Site W
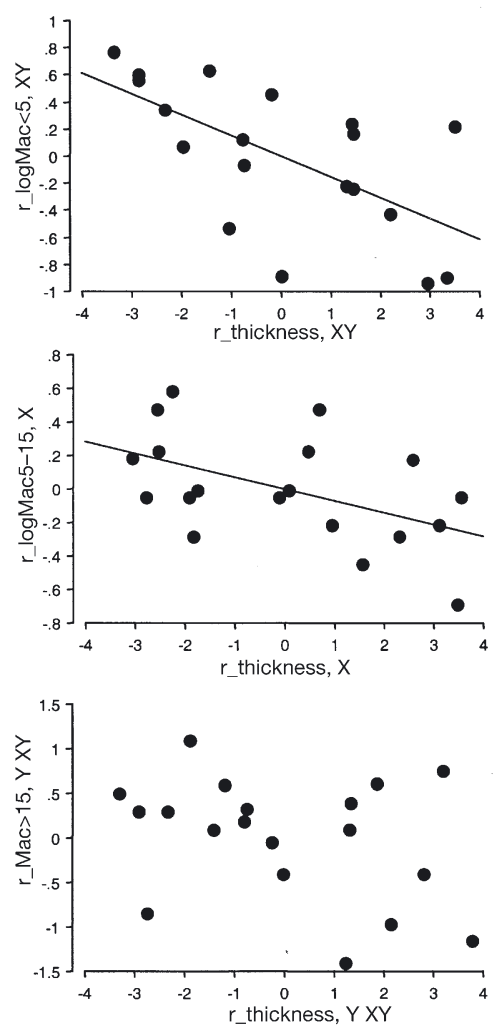

Thickness of deposit when core was collected $(\mathrm{mm})$

Fig. 5. Austrovenus stutchburyi, Macomona liliana. Response of 2 common bivalve species to layers of terrigenous sediment of varying thickness in Expt 1 . Three size classes $(<5,5$ to 15 , and $>15 \mathrm{~mm}$ maximum width) were analyzed for each. Partial regression leverage plots are given in 7 of the 9 panels where positional effects (indicating underlying gradients in abundance across- and down-shore) were significant. Partial regression leverage plots show the response to deposit thickness alone, after removing the influence of spatial variables that were significant

positive or negative response) is not explicit in such techniques. Thus, we also analyzed how the numbers of taxa and individuals per core varied by treatment. The thickness of terrigenous sediment in plots at the end of the experiment was related to both of these community measures (ANCOVA, p $<0.0001$, both cases). The slopes relating community response to deposit thickness did not differ by site, as indicated by insignificant site $\times$ deposit thickness interaction terms ( $\mathrm{p}=0.8321$ for taxa, $\mathrm{p}=0.9057$ for individuals), and slope estimates were negative for both community measures $(-0.5878$ for taxa, $\mathrm{p}=0.0064 ;-0.1620$ for individuals, $\mathrm{p}=0.0058$ ). This indicated a general response of the Whitford sandflat macrofauna to the deposition of terrigenous sediment, namely, a significant decline in the number of taxa and individuals even when the terrigenous deposits were $<1 \mathrm{~cm}$ deep.

Quantifying the response of individual taxa across the 4 sites was more difficult, for few species were common enough across all sites for analysis. However, the bivalve Macomona liliana declined with increasing deposit thickness (ANCOVA $\mathrm{p}<0.0001$, slope estimate $-0.1991, \mathrm{p}=0.1026)$, consistent with the results we observed for this species in Expts 1 and 2.

\section{DISCUSSION}

In this study, we provided insights into the effects of thin deposits of terrigenous sediment by performing manipulative experiments in several intertidal habitats in a New Zealand embayment. We collected topsoil from the Whitford catchment, mixed it with seawater from the Whitford embayment, and deposited the terrigenous material in experimental plots on Whitford's intertidal flats. The material we used and the thickness of the deposits we created realistically mimicked a type of disturbance that may be frequent and widespread in New Zealand and throughout the Pacific Rim. 


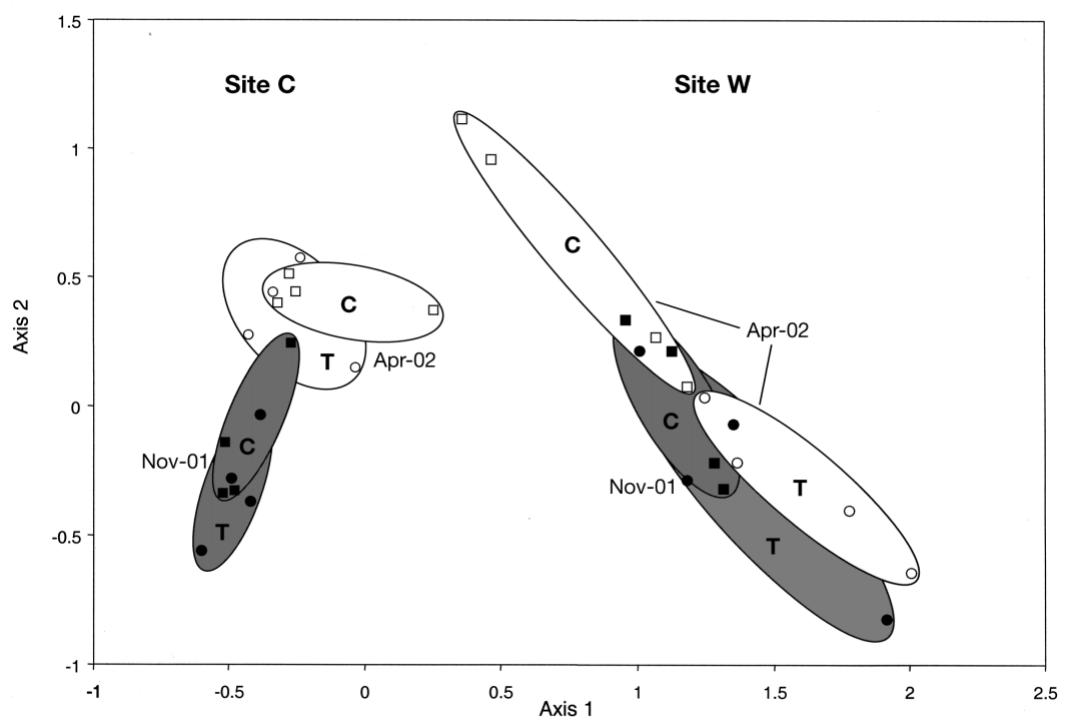

Fig. 6. Ordination of macrobenthic community data collected during Expt 2 ( 2 sites, on 2 dates). Ovals encompass the ordination space occupied by 4 experimental plots $(\mathrm{T}=$ treatments with $3 \mathrm{~mm}$ of terrigenous sediment, $\mathrm{C}$ $=$ controls with no terrigenous sediment). Individual data points are shown as small symbols (treatments $=$ circles, controls $=$ squares). Treated plots in November (gray ovals, filled symbols) had 1 single application of sediment, whereas treated plots in April (white ovals, open symbols) had been exposed to terrigenous material 6 times over a 6 mo period, before macrofaunal cores were collected (see 'Materials and methods'). The differences in macrobenthic community composition increased with repeated exposure to terrigenous sediment, especially at Site W
By applying multivariate statistical techniques, we were able to interpret the aggregated responses of macrobenthic communities at each of the sites. The results are thus integrated measures of effects that span across a range of species that vary in sensitivity. Results indicated that as little as $3 \mathrm{~mm}$ of sediment was sufficient to alter macrobenthic community structure, reducing the number of taxa, the density of individuals, and the densities of particular common species. The number of taxa and individuals declined by nearly $50 \%$ in treatments that received $7 \mathrm{~mm}$ of terrigenous sediment.

The patterns of macrobenthic response were similar across a suite of experimental sites, suggesting that thin layers of terrigenous material can disturb several distinctive macrobenthic community types. The effects also spanned a broad range of taxa (e.g. amphipods, bivalves, gastropods, and polychaetes) and functional types (e.g. suspension feeders, surface- and sub-surface deposit feeders). Overall, responses were strongest for taxa associated with the sediment-water interface, where the terrigenous material was experimentally depo-

Table 5. Physical and biogeochemical characteristics of sediments at the end of Expt 3. Particle-size distribution of sediments is given as \% volumetric composition (mean values $\pm 1 \mathrm{SE}$ )

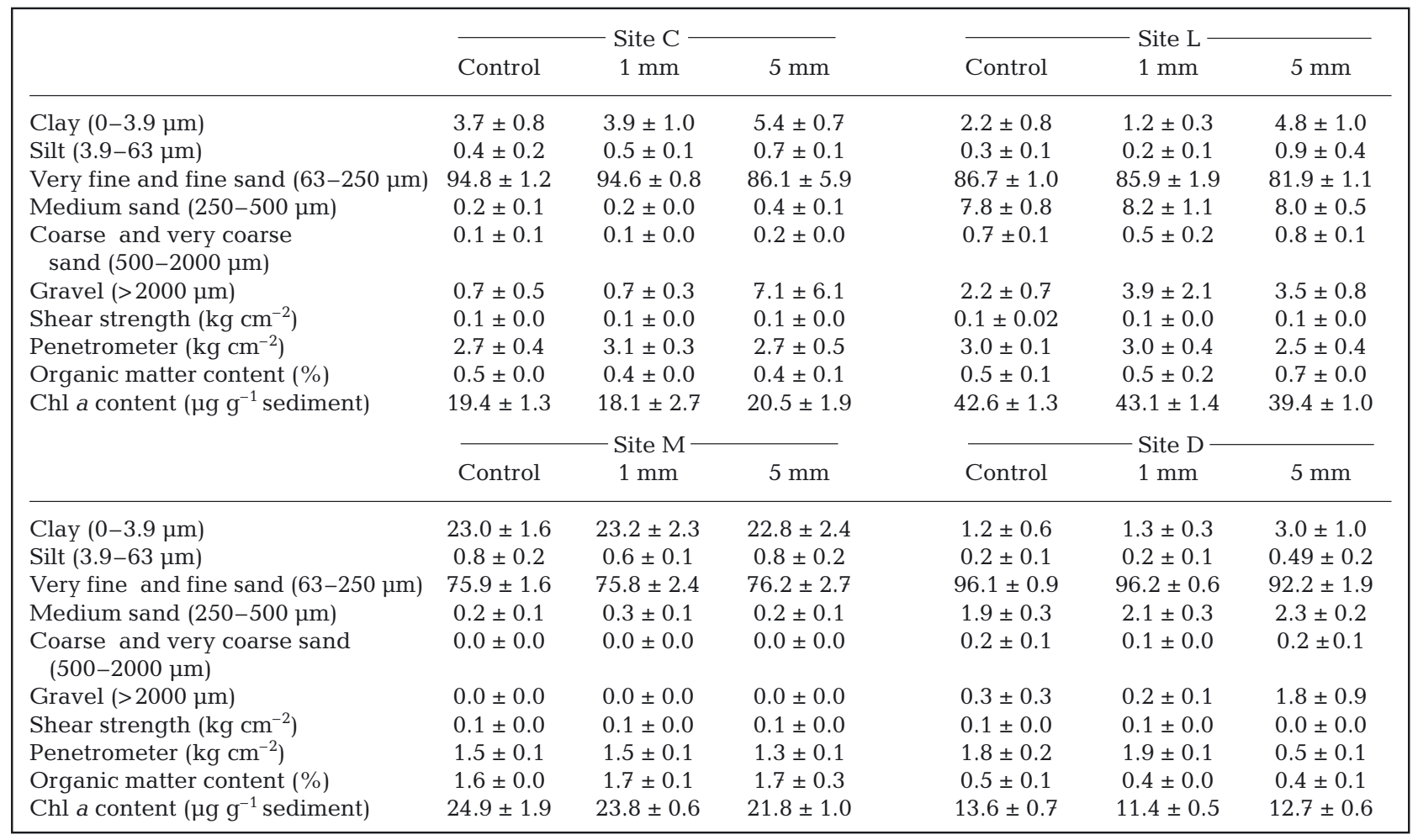




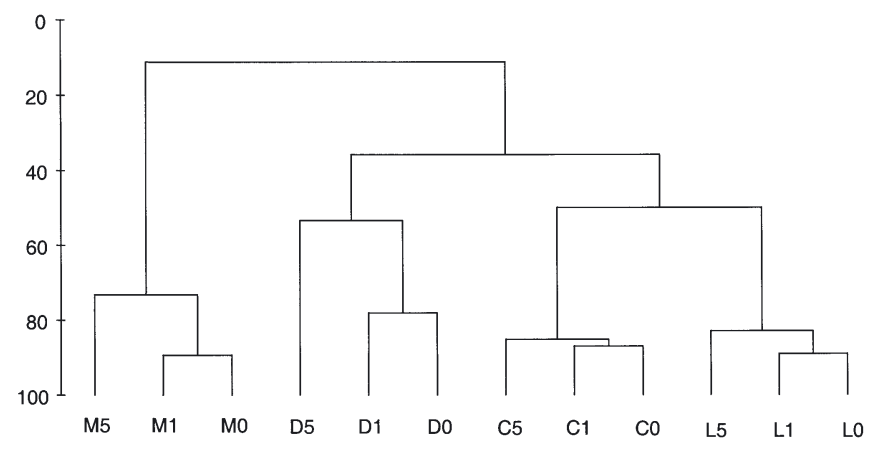

Fig. 7. Cluster analysis of macrobenthic data collected from 4 sites at the end of Expt 3. Combinations of site $(C, D, L, M)$ and treatment $(0=$ control, $1=1 \mathrm{~mm}, 5=5 \mathrm{~mm})$ are indicated on the figure to show differences in macrofaunal community composition in relation to deposit thickness. The figure presented is based on mean data per treatment (square-root transformed). The $5 \mathrm{~mm}$ treatments differed the most from controls at each of the 4 sites

sited. Finally, the benthos did not appear to recover fully between repeated depositional events (occurring monthly during summer), implicating chronic terrigenous sediment loading as a potential source of habitat degradation in estuarine and coastal systems.

The terrigenous sediment layers that were deposited on intertidal sandflats during the study remained in place for days to weeks. For example, layers 3 to $7 \mathrm{~mm}$ thick were only diminished by ca. $50 \%$ during the $10 \mathrm{~d}$ experiments. However, in $1 \mathrm{~mm}$ treatments, most of the terrigenous sediment in the deposits had disappeared by the end of the experiments. In all cases, the terrigenous material was not detected 1 mo after deposition. We identified 3 contributing factors: (1) burial of the deposits by sediments moving laterally across the seabed, (2) removal of the deposits by erosion, and (3) bioturbation. Water movement associated with windwaves and tidal currents was likely responsible for the first 2 mechanisms of terrigenous sediment removal. Fine sands were observed atop the experimental deposits in most plots after $10 \mathrm{~d}$, confirming Point 1 . The sand from outside the plots tended to collect in long rows (e.g. as sand ripples), and the distinctly colored terrigenous material remained visible between rows. Just as sand was advected into the plots, it is likely that terrigenous sediment was eroded out of the treatments, but this loss could not be quantified. Following the repeated application of terrigenous material over a 6 mo period (Expt 2), the sediments had a net increase in clay content. This indicated that at least some of the terrigenous materials we deposited became incorporated and down-mixed into the sediment column.

In subtidal areas and tidal channels adjacent to the Whitford sandflat habitats, ocypodid and grapsid crabs are important agents of sediment bioturbation because
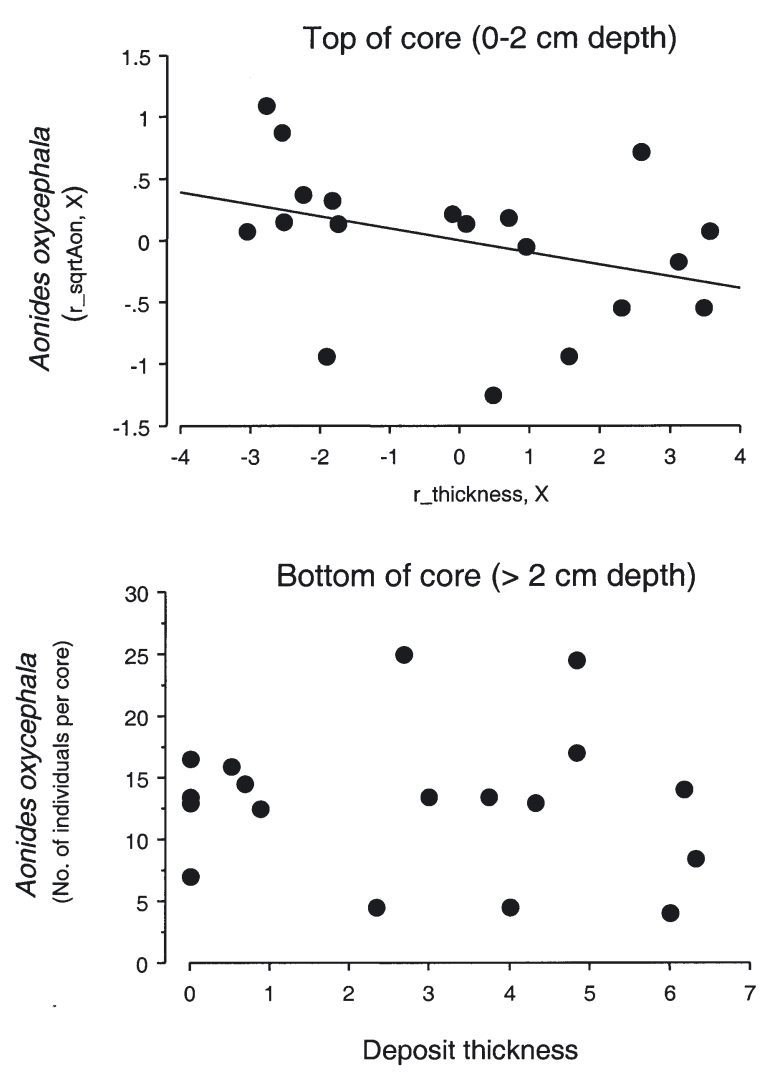

Fig. 8. Aonides oxycephala. Response to terrigenous layers applied at Site W in Expt 1. Cores were sliced into 2 sections (a 0 to $2 \mathrm{~cm}$ surficial layer, and a 2 to $15 \mathrm{~cm}$ deep layer), and response of $A$. oxycephala was analyzed for each. While there was no significant response to terrigenous sediment in the deep layer (bottom panel), A. oxycephala in the surface layer responded negatively to terrigenous sediment deposition (partial regression leverage plot, upper panel) (see also bottom of Table 4)

of their relatively large size, mobility, and propensity to excavate complicated burrow structures. However, few crabs were found in, or were attracted to, the experimental plots used during the present study. This contrasts with previous catastrophic sedimentation experiments, where mud crabs increased dramatically in response to terrigenous sediment deposition (Norkko et al. 2002, Thrush et al. 2003). Nevertheless, since the thin layers of terrigenous sediment deposited during the present study did not defaunate the plots or exterminate selected taxa, the potential for organismmediated sediment mixing remained possible. Thus animal movements associated with burrowing and feeding likely displaced some of the terrigenous material deposited atop the sediment surface.

In situations where lateral advection along the seabed makes significant contributions to the recovery process (e.g. Point 1 above), the scale of disturbance can profoundly influence results (Zajac et al. 1998, 
Langton \& Auster 1999, Lohrer \& Whitlatch 2002). As the radius $(r)$ of a terrigenous deposit becomes larger, its ratio of edge to interior area declines as a function of $2 / r$. Thus, with spatially extensive depositional events, the lateral advection of sand from outside the disturbed area may not contribute as much to the recovery process as it did in our experiments, which involved manipulations of relatively small plots with large edge:interior ratios. However, the size of our plots and the timescales over which we monitored a response were appropriate to determine the immediate effects of terrigenous material deposition on macrofaunal communities in Whitford sandflat habitats. Furthermore, while the longer-term effects of terrigenous sediment deposition may be more scale-dependent, we were still able to demonstrate a gradual degradation in macrobenthic communities using small plots. This implies that largerscale events, more typical of what occurs in the natural environment, would have even greater effects.

While species with high abundance were affected by the application of terrigenous sediment, they generally did not disappear. Rare species, in contrast, likely declined to levels below the detection threshold. Logically, species represented by just 1 or 2 individuals per core would, by chance, be present in fewer cores following a $50 \%$ decline in abundance. Thus the decline in number of taxa per core in treated plots (scored by presence-absence) was likely correlated to overall declines in abundance associated with the treatments.

The terrigenous material deposited at the sediment surface appeared to have a disproportionate effect on smaller-sized organisms, as demonstrated by the response of 3 common bivalves (Austrovenus stutchburyi, Macomona liliana, Nucula hartvigiana). The smallest size class of bivalves (i.e. $<5 \mathrm{~mm}$ wide) declined the most following the experimental additions of terrigenous sediment (Fig. 5), whereas the largest bivalves $(>15 \mathrm{~mm})$ were essentially unaffected. Several factors could have contributed to this result. First, large bivalves generally live deeper in the sediment column than smaller conspecific ones, as their proportionally longer siphons allow them to burrow deeper to avoid predation by fishes and shorebirds (Irlandi \& Mehlich 1996, de Goeij et al. 2001, Lardies et al. 2001). Consequently, in this case, the larger bivalves may have been further away from the environmental stressor, namely the terrigenous sediment deposited at the surface. Secondly, large bivalves likely have greater energy reserves than smaller ones (Elner \& Hughes 1978, Yukihira et al. 1998). Thus, if the terrigenous deposits interrupted feeding, larger bivalves were probably better able to cope with starvation than smaller bivalves of the same species. Thirdly, size is correlated with age and experience. Older bivalves may have been better conditioned to cope with envi- ronmental stress, if past experiences had increased their levels of tolerance (Wiens et al. 2000, Drew et al. 2001, Helmuth \& Hofmann 2001). Lastly, small Austrovenus and Macomona can actively disperse after adopting a benthic lifestyle (Cummings et al. 1993, 1995, Norkko et al. 2001), and poor habitat quality is 1 factor capable of inducing post-settlement movement behaviors in these species (V. J. Cummings pers. comm.). However, since dead/empty shells were not quantified, we could not determine whether the terrigenous sediment treatment killed the small bivalves or whether they emigrated from the plots following clay application.

Several common polychaete species (e.g. Aquilaspio aucklandica, Orbinia papillosa, Heteromastus filiformis, Scoloplos cylindrifer) responded similarly to the treatments applied in Expt 1, despite substantial differences in their general ecology. Densities of each species declined with increased thickness of the terrigenous deposits (Table 4, Fig. 3). One feature common to each species was a predominant association with the upper veneer of the sediment column $(0$ to $2 \mathrm{~cm}$ from the surface).

The spionid polychaete Aonides oxycephala was the exception, in that we detected no overall response to terrigenous material deposition in Expt 1. This species was more common at depths $>2 \mathrm{~cm}$ in the sediment column, physically separating it from the location of surficial sediment deposition. To better understand this pattern, we analyzed the response of Aonides present in different portions of the sediment column at Site W. Those individuals present near the top of the sediment column (in the 0 to $2 \mathrm{~cm}$ depth stratum) declined with increasing deposit thickness, whereas individuals $>2 \mathrm{~cm}$ deep were unaffected (Fig. 8). Thus, the impact of terrigenous layers $<1 \mathrm{~cm}$ thick at the surface of the sedimemt apparently did not influence certain organisms living $>2 \mathrm{~cm}$ deep in the sediment column during this experiment.

The mechanisms responsible for the effects we observed remain largely unidentified, though the addition of terrigenous sediment apparently changes habitat properties significantly and quickly. For example, Cummings et al. (2003) documented in detail some of the differences between terrigenous deposits and New Zealand sandflat sediments. They made measurements of total microbial biomass, total carbohydrates, total proteins, pore-water nitrogen and phosphorus, chl $a$, phaeophytin, \% carbon, \% loss of ignition, and sediment particle-size distribution. Additional measurements of sediment porosity, pore water composition, benthic oxygen production, and nutrient flux rates associated with our treatments at Whitford (M. Gibbs unpubl.) indicated potentially important changes to sediment biogeochemistry. 
In short, a mechanistic understanding of why terrigenous sedimentation disturbs intertidal macrofauna requires further study, but we have convincing evidence that even small amounts of terrigenous sediment can act as a disturbance agent in this habitat type. None of the common species we collected were completely immune to the short-term effects of terrigenous sediment deposition. Three species that showed mild responses were Heteromastus filiformis (a capitellid polychaete generally associated with muddy sediments), Scoloplos cylindrifer (a sub-surface deposit feeder), and Aonides oxycephala (the deep-dwelling polychaete mentioned above).

\section{CONCLUSIONS AND CONTEXT}

Terrigenous sediment deposition has become increasingly recognized as a problem for 2 principal reasons. First, anthropogenic perturbations of terrestrial habitats have likely increased the loadings of terrigenous materials to the coastal ocean and, with human populations expanding, rates of terrigenous sedimentation may continue to rise. Secondly, because the physical and chemical characteristics of terrigenous sediments can differ substantially from those typical of the marine environment (Cummings et al. 2003), the recovery time following a massive depositional event can be extremely slow (Norkko et al. 2002, Thrush et al. 2003). The colonization of the disturbed habitats by macrofauna is probably dependent on the break-up and redistribution of the terrigenous layers. Since the macrofauna themselves are a significant force driving sediment redistribution (i.e. via bioturbation), deterrence to colonization likely has a compounding effect on sediment recovery.

The impacts of thin $(<1 \mathrm{~cm})$ terrigenous deposits have not received the same scrutiny as thick (2 to $10 \mathrm{~cm}$ ) deposits (Peterson 1985, Norkko et al. 2002, Cummings et al. 2003, Hewitt et al. 2003, Thrush et al. 2003). While the magnitude of effects caused by thin deposits may be comparatively less (e.g. sub-lethal), thin layers are probably deposited much more often. In fact, the relationship between deposit depth and deposit frequency is likely negatively exponential, given that coastal catchments are prime examples of critical systems that typically operate in this manner (Bak 1997, Sornette 2000). Thus, determining the minimum amount of terrigenous material that constitutes a disturbance is necessary if we are to predict the outcome of changing sediment delivery regimes.

Results from the present study indicate that terrigenous deposits $<1 \mathrm{~cm}$ thick can negatively influence macrobenthic community structure, which suggests that the effects of sediment loading may be more frequent and more widespread than previously thought. Deposits of greater thickness can cover hundreds of square kilometers following significant flooding events (Wheatcroft 2000, Hunt 2002). Futhermore, the effects demonstrated in the present study are not likely due to specific properties of the Whitford topsoils; experimental studies using topsoils from Okura, Whangapoua, Whitianga, and Mahurangi (other estuarine catchments in northern New Zealand) all produced significant negative changes to macrofauna in those respective estuaries (Norkko et al. 2002, Cummings et al. 2003, Hewitt et al. 2003, Thrush et al. 2003). Finally, factors that produce large episodic deposits of terrigenous sediment in marine habitats (heavy rainfall, steep hillsides, river characteristics) are not limited to New Zealand, but are in fact common in many parts of Asia and the Pacific (Milliman \& Meade 1983). Human land-use practices in coastal catchments in densely populated, less environmentally regulated regions may elevate sedimentation rates well beyond those of New Zealand.

Measurements of typical and extreme sediment loads are required to better understand the regime of terrigenous material deposition in marine habitats and the generality of this type of disturbance. Hydrodynamic catchment models could then be employed to predict the likelihood of occurrence of deposits of a given thickness per unit time (i.e. to define the relationship between disturbance intensity and disturbance frequency). Run under a range of different landuse scenarios, the models would greatly facilitate risk assessment for embayments such as Whitford, by linking results from empirical studies such as this one (quantitative information about the effects of terrigenous sedimentation) to a greater recognition of the impact of urban and semi-rural development.

Acknowledgements. We wish to thank G. Funnell, P. Nicholls, A. Norkko, J. Norkko, C. Lundquist, M. Gibbs, and P. Herman and many others at NIWA for assistance with various aspects of the study. M. Delafontaine, B. Flemming, and 2 anonymous reviewers provided very thorough reviews and many insightful comments. The Auckland Regional Council supported this work financially (Contract No. ARC01269), provided assistance in obtaining terrigenous sediment, permitted us to conduct the experiment in the Whitford embayment, and allowed us to publish the results of the work. Additional financial support was granted by the New Zealand Foundation for Research Science and Technology (FRST Contract No. CO1X0307).

\section{LITERATURE CITED}

Bak P (1997) How nature works: the science of self-organized criticality. Oxford University Press, Oxford Clark KR, Gorley RN (2001) Primer v5. Primer-E, Plymouth 
Connell JH (1978) Diversity in tropical rain forests and coral reefs. Science 199:1302-1310

Connell JH, Slatyer RO (1977) Mechanisms of succession in natural communities and their role in community stability and organization. Am Nat 111:1119-1144

Cummings VJ, Pridmore RD, Thrush SF, Hewitt JE (1993) Emergence and floating behaviors of post-settlement juveniles of Macomona liliana (Bivalvia: Tellinacea). Mar Behav Physiol 24:25-32

Cummings VJ, Pridmore RD, Thrush SF, Hewitt JE (1995) Post-settlement movement by intertidal benthic macroinvertebrates: do common New Zealand species drift in the water column? NZ J Mar Freshw Res 29:59-67

Cummings V, Thrush S, Hewitt J, Norkko A, Pickmere S (2003) Terrestrial deposits on intertidal sandflats: sediment characteristics as indicators of habitat suitability for recolonising macrofauna. Mar Ecol Prog Ser 253:39-54

Dayton PK (1971) Competition, disturbance, and community organization: the provision and subsequent utilization of space in a rocky intertidal community. Ecol Monogr 41: 351-389

de Goeij P, Luttikhuizen PC, van der Meer J, Piersma T (2001) Facilitation on an intertidal mudflat: the effect of siphon nipping by flatfish on burying depth of the bivalve Macoma balthica. Oecologia 126:500-506

Denslow JS (1980) Pattern of plant species diversity during succession under different disturbance regimes. Oecologia 46:18-21

Drew B, Miller D, Toop T, Hanna P (2001) Identification of expressed HSP's in blacklip abalone (Haliotis rubra Leach) during heat and salinity stresses. J Shellfish Res 20: 695-703

Dudgeon S, Petraitis PS (2001) Scale-dependent recruitment and divergence of intertidal communities. Ecology 82: 991-1006

Ellis JI, Norkko A, Thrush SF (2000) Broad-scale disturbance of intertidal and shallow sublittoral soft-sediment habitats; effects on the benthic macrofauna. J Aquat Ecosyst Stress Recovery 7:57-74

Ellis JI, Cummings V, Hewitt J, Thrush S, Norkko A (2002) Determining effects of suspended sediment on condition of a suspension feeding bivalve (Atrina zelandica): results of a survey, a laboratory experiment and a field transplant experiment. J Exp Mar Biol Ecol 267:147-174

Elner RW, Hughes RN (1978) Energy maximization in the diet of the shore crab, Carcinus maenas. J Anim Ecol 47: $103-116$

Foster G, Carter L (1997) Mud sedimentation on the continental shelf at an accretionary margin-Poverty Bay, New Zealand. NZ J Mar Freshw Res 40:157-173

GESAMP (1994) Anthropogenic influences on sediment discharge to the coastal zone and environmental consequences. UNESCO-TOC, Paris

Grant J, Bacher C (1998) Comparative models of mussel bioenergetics and their validation at field culture sites. J Exp Mar Biol Ecol 219:21-44

Gray JS (1997) Marine biodiversity: patterns, threats and conservation needs. Biodiversity Conserv 6:153-175

Helmuth BST, Hofmann GE (2001) Microhabitats, thermal heterogeneity, and patterns of physiological stress in the rocky intertidal zone. Biol Bull 201:374-384

Hewitt JE, Cummings VJ, Ellis JI, Funnell G, Norkko A, Talley TS, Thrush SF (2003) The role of waves in the colonization of terrestrial sediments deposited in the marine environment. J Exp Mar Biol Ecol 290:19-47

Hobbs RJ, Mooney HA (1991) Effects of rainfall variability and gopher disturbance on serpentine annual grassland dynamics. Ecology 72:59-68

Hunt L (2002) An X-radiographic study of the October 2000 Po River flood deposit, Italy. MSc, Oregon State University, Corvallis, OR

Huston MA (1979) A general hypothesis of species diversity. Am Nat 113:81-101

Irlandi EA, Mehlich ME (1996) The effect of tissue cropping and disturbance by browsing fishes on growth of two species of suspension-feeding bivalves. J Exp Mar Biol and Ecol 197:279-293

Langton RW, Auster PJ (1999) Marine fishery and habitat interactions: to what extent are fisheries and habitat interdependent? Fisheries 24:14-21

Lardies MA, Clasing E, Navarro JM, Stead RA (2001) Effects of environmental variables on burial depth of two infaunal bivalves inhabiting a tidal flat in southern Chile. J Mar Biol Assoc UK 81:809-816

Legendre P, Legendre L (1998) Numerical ecology. Elsevier, Amsterdam

Levinton JS (1972) Stability and trophic structure in depositfeeding and suspension-feeding communities. Am Nat 106:472-486

Lohrer AM, Whitlatch RB (2002) Modeling life-stage based dynamics of marine invertebrates in soft-sediment habitats: some implciations for habitat conservation. In: Lindholm JB, Ruth M (eds) Dynamic modeling for marine conservation. Springer-Verlag, New York, p 191-213

Lopez G, Taghon G, Levinton JS (1989) Ecology of marine deposit feeders. Springer-Verlag, New York

Lunden CG, Linden O (1993) Coastal ecosystems: attempts to manage a threatened resource. Ambio 22:468-473

Marinelli RL, Woodin SA (2002) Experimental evidence for linkages between infaunal recruitment, disturbance and sediment surface chemistry. Limnol Oceanogr 47:221-229

McKnight DG (1969) A recent, possible catastrophic burial in a marine molluscan community. NZ J Mar Freshw Res 3: $177-179$

Menge BA, Sutherland JP (1987) Community regulation: variation in disturbance, competition, and predation in relation to envirornmental stress and recruitment. Am Nat 130:730-757

Milliman JD (1991) Flux and fate of fluvial sediment and water in coastal seas. In: Mantoura RFC, Martin JM, Wollast R (eds) Ocean margin processes in global change. John Wiley \& Sons, Chichester, p 69-89

Milliman JD, Meade RH (1983) World-wide delivery of river sediment to the oceans. J Geol 91:1-21

Mook DH (1981) Effects of disturbance and initial settlement on fouling community structure. Ecology 62:522-526

Moreno JM, Oechel WC (1991) Fire intensity effects on germination of shrubs and herbs in Southern California chaparral. Ecology 72:1993-2004

Norkko A, Cummings V, Hewitt J, Hume T (2001) Local dispersal of juvenile bivalves: implications for sandflat ecology. Mar Ecol Progr Ser 212:131-144

Norkko A, Thrush S, Hewitt J, Cummings V and 5 others (2002) Smothering of estuarine sandlfats by terrigenous clay: the role of wind-wave disturbance and bioturbation in site-dependent macrofaunal recovery. Mar Ecol Prog Ser 234:23-41

Peddicord RK (1976) Effects of substratum on growth of the bivalve Rangia cuneata Gray, 1831. Veliger 18:398-404

Peterson CH (1985) Patterns of lagoonal bivalve mortality after heavy sedimentation and their paleoecological significance. Paleobiology 11:139-153

Pickett STA, White PA (1985) The ecology of natural disturbance and patch dynamics. Academic Press, New York 
Rhoads DC, Young DK (1970) The influence of deposit-feeding organisms on sediment stability and community trophic structure. J Mar Res 28:150-178

Rhoads DC, McCall PT, Yingst JY (1978) Disturbance and production on the estuarine seafloor. Am Sci 66:577-586

Rothman DH, Grotzinger JP, Flemings P (1994) Scaling in turbidite deposition. J Sediment Res 64:59-67

Sartory DP (1982) Spectrophotometric analysis of chlorophyll $a$ in freshwater phytoplankton. Technical Report TR 115. Hydrological Research Institute, Department of Environmental Affairs, Pretoria

Somfai E, Czirok A, Vicsek T (1994) Roughening in a model experiment on erosion in geomorphology. J Physics 205: $355-371$

Sornette D (2000) Critical phenomena in natural sciences. Springer-Verlag, Berlin

Sousa WP (1984) The role of disturbance in natural communities. Annu Rev Ecol System 15:353-391

Sutherland JP (1974) Multiple stables points in natural communities. Am Nat 108:859-873

Thrush S, Whitlatch RB, Pridmore RD, Hewitt J, Cummings V, Wilkinson MR (1996) Scale-dependent recolonization: the role of sediment stability in a dynamic sandflat habitat. Ecology 77:2471-1487

Thrush SF, Hewitt JE, Norkko A, Cummings VJ, Funnell GA (2003) Macrobenthic recovery processes following catastrophic sedimentation on estuarine sandflats. Ecol Appl 13:1433-1455

Thrush SF, Lundquist CJ, Hewitt JE (in press) Spatial and temporal scales of disturbance to the seafloor: a generalised framework for active habitat management. In:

Editorial responsibility: John Gray,

Oslo, Norway
Barnes PW, Thomas JP (eds) Benthic habitats and the effects of fishing. American Fisheries Society Symposium Series, Bethesda, MD

Tokeshi M (1999) Species coexistence: ecological and evolutionary perspectives. Blackwell Science, London

Wheatcroft RA (2000) Oceanic flood sedimentation: a new perspective. Cont Shelf Res 20:2059-2066

Wiens M, Ammar MSA, Nawar AH, Koziol C, Hassanein HMA, Eisinger M, Mueller IM, Mueller WEG (2000) Induction of heat-stock (stress) protein gene expression by selected natural and anthropogenic disturbances in the octocoral Dendronephthya klunzingeri. J Exp Mar Biol Ecol 245:65-276

Wilson SD, Tilman D (1993) Plant competition and resource availability in response to disturbance and fertilization. Ecology 74:599-611

Woodin SA (1981) Disturbance and community structure in a shallow water sand flat. Ecology 62:1052-1066

Woodin SA, Marinelli RL, Lindsay SM (1998) Process-specific cues for recruitment in sedimentary environments: geochemical signals? J Mar Res 56:535-558

Yodzis P (1986) Competition, mortality, and community structure. In: Diamond J, Case TJ (eds) Community ecology. Harper \& Row, New York, p 480-491

Yukihira H, Klumpp DW, Lucas JS (1998) Effects of body size on suspension feeding and energy budgets of the pearl oysters Pinctada margaritifera and P. maxima. Mar Ecol Prog Ser 170:119-130

Zajac RN, Whitlatch RB, Thrush S (1998) Recolonization and succession in soft-sediment infaunal communities: the spatial scale of controlling factors. Hydrobiologia 375/376: $227-240$

Submitted: August 7, 2003; Accepted: February 25, 2004 Proofs received from author(s): May 27, 2004 